\title{
Erken Cumhuriyet Döneminde Türkiye Cumhuriyeti ile Sovyetler Birliği Arasındaki Sanatsal İlişskiler: “Ankara: Türkiye’nin Kalbi” Belgeseli Örneği
}

\author{
YALÇIN LÜLECI* \\ yalcinluleci@yandex.com
}

\begin{abstract}
Özet: Kurtuluş Savaşı̇nın devam ettiği günlerde Batılı devletlere karşı Ankara Hükümeti ile Sovyet Rusya arasında kurulan yakın siyasi ilişkiler, Cumhuriyet'in 1923'teki ilanından II. Dünya Savaşı'nın 1945'te sona ermesine kadar devam etmiştir. Bahsedilen dönemde, iki ülke arasında gerçekleşen ve siyasi, askeri ve iktisadi yönleri ağır basan bu ilişkilerin bir boyutunu da sanat oluşturmuştur. Çarlık döneminden sanatsal açıdan önemli bir miras devralan ve sosyalist ideolojinin propagandasında sanata özel bir misyon yükleyen Sovyetler Birliği ile Batılı sanatlarm eğitimini yayginlaştırmayl, sanatçıları desteklemeyi ve bunun sonucunda nitelikli sanat eserlerinin üretilmesini, bir "uygarlaşma" ölçüsü olarak gören ve Atatürk ilke ve inkılaplarını halka iletmekte sanatın propaganda gücünden faydalanmayı düşünen Türkiye Cumhuriyeti, özellikle 1930'lu yillarda sanat alanında bir işbirliğinde bulunmuşlardır. Bu kapsamda, Türk hükümeti tarafindan "Cumhuriyet'in Onuncu Yil Kutlamalari” çerçevesinde Türkiye’ye davet edilen Sovyet sinemacılar tarafından çekimi gerçekleştirilen "Türkiye’nin Kalbi: Ankara" filmi, özel bir anlam ifade etmektedir. Bu çalışma, Cumhuriyetin ilk yillarında Türkiye Cumhuriyeti ve Sovyetler Birliği arasında sanat alanında gerçekleşen işbirliği ve etkileşimi ele almakta ve bu ilişkinin boyutlarım kapsamlı olarak ortaya koymayı amaçlamaktadır.
\end{abstract}

Anahtar kelimeler: Türk-Sovyet ilişkileri, Ankara: Türkiye’nin kalbi, Cumhuriyet, Sanat, Sinema

\section{Giriş}

1917 yılında Bolşevik Devrimi’yle Rusya'da iktidara gelen Sovyet Hükümeti, 3 Aralık 1917 tarihinde Rusya ve Doğu Müslümanlarına hitaben yayınladığı bildiriyle; Müslüman halkları Bolşevik rejimini desteklemeye ve emperyalizmine karşı ayaklanmaya çağırmıştır. Bolşevikler bu bildiriyle ayrıca, Çarlık Rusyası’nın Osmanlı Devleti’ni parçalayan antlaşmalarını tanımadıklarını ve İstanbul'un Türklerin elinde kalmasından yana olduklarını da ilan etmişlerdir. Ankara'da Büyük Millet Meclisi’nin açılmasından üç gün sonra -26 Nisan 1920'deMustafa Kemal, Lenin'e gönderdiği bir mektupla, Ankara ve Moskova arasında askeri ve siyasi bir ittifak kurularak emperyalizme karşı, birlikte mücadele edilmesini teklif etmiş ve Sovyetler Birliği’nin, bu mektuba 3 Haziran 1920'de cevap vermesiyle de iki hükümet arasında diplomatik ilişkiler kurulmuştu. ${ }^{1} 16$ Mart 1921 tarihinde Türkiye ile Sovyetler Birliği arasında imzalanan Moskova Antlaşması’yla Sovyetler, Sevr Antlaşması’nı geçersiz saymış, Ankara Hükümeti’ni tanımış ve Kars, Ardahan, Artvin Türkiye’ye, Batum Gürcistan’a, Nahçivan Azerbaycan’a bırakılmıştır. Sovyetler, Büyük Millet Meclisi’nin tanımayacağı hiçbir

\footnotetext{
* Öğr. Gör. Dr., Marmara Üniversitesi, İletişim Fakültesi.

${ }^{1}$ Mustafa Balcıoğlu, "Direnen Millet - Milli Mücedele: Ya İstiklâl Ya Ölüm”, Türkiye Cumhuriyeti Tarihi. Cilt:I, Ankara: AKDTYK Atatürk Araştırma Merkezi, 2005, s. 224-225.
} 
antlaşmayı tanımayacaktı. Bu antlaşmayla Türk-Rus sınırı çizilmiş ve kapitülasyonların kaldırılması Sovyetler tarafından kabul edilmişti. Sovyetler, Türkiye’ye iki tümen askere yetecek kadar silah ve cephane yardımı ve on milyon altın ruble yardımda bulunacaktı. Bunların yanında Sovyetler, Boğazların Türk hâkimiyetinde kalmasını ve Boğazların statüsünün Karadeniz’e kıyı devletler tarafından belirlenmesini de kabul etmiştir. 13 Ekim 1921'de ise Kars'ta Türkiye, Gürcistan, Azerbaycan ve Ermenistan Sovyet Sosyalist Cumhuriyetleri ile Kars Antlaşması imzalanmıştır. Bu antlaşmayla adı geçen devletler, Moskova Antlaşması'nda belirlenen sınırları onaylamışlardır. ${ }^{2}$

Türkiye ile İngiltere arasında Musul’un statüsü konusundaki görüşmelerin gergin bir hal alması ve 1 Aralık 1925’te İngiltere, Fransa, İtalya, Belçika, Polonya ve Çekoslovakya’nın imzaladıkları Locarno Anlaşmasıłyla Almanyảnın Batılıların yanında yer alması ihtimalinin belirmesi sonucunda 17 Aralık 1925’te Türkiye ile Sovyetler Birliği arasında “Dostluk ve Saldırmazlık Antlaşması" imzalanmıştır. Üç yıl geçerli olacak bu antlaşmaya göre, "taraflardan birine, bir veya birkaç devlet tarafından yöneltilen bir askeri hareket halinde diğeri tarafsız kalacak ve birbirlerine saldırmayacakları gibi, birbirleri aleyhine yönelen ittifak veya siyasi anlaşmalara da katılmayacaklardı.” ${ }^{3}$ Türkiye ve Sovyetler Birliği arasında gelişen ilişkiler sonucunda, 1925 tarihli "Dostluk ve Tarafsızlık Antlaşması" ile bunun uzatılması hakkındaki 17 Aralık 1929 ve 30 Ekim 1931 tarihli iki protokol ve esas antlaşmaya ek olarak 7 Mart 1931 tarihli "Deniz Protokolü” de imzalanmıştır. 7 Kasım 1935 tarihinde ise, bu anlaşmaların 7 Kasım 1945 tarihine kadar on yıl süre ile uzatılmasını öngören bir protokol imzalanmıştır. 1936 yılına kadar olumlu bir şekilde gelişen ilişkiler, bu yıl toplanan Montreux Konferansı’nda ve sonraki yıllarda Türkiye’nin İngiltere ile işbirliği yapması üzerine zayıflamaya başlamıştır. ${ }^{4} \mathrm{Bu}$ iyileşmenin temelinde, Türkiye’nin, Fransa ve İngiltere ile birlikte, dönemin mevcut siyasal statükosunu desteklemesi ve Avrupa haritasını yeniden çizmek isteyen Nazi Almanyası ve Faşist İtalya gibi "revizyonist" devletlere karşı tavır alması yatıyordu. Sovyetler Birliğinnin de "anti-revizyonist" gruba katılması, Türkiye’nin Batı ülkeleriyle olan yakınlaşmasını kolaylaştırmıștır. ${ }^{5}$

Sovyetler Birliği ile Türkiye arasında ilişkilerin iyi gittiği bu dönemde, ele aldığımız konu açısından önemli olan, Türkiye Cumhuriyeti’nin 10. Kuruluş Yıldönümü etkinliklerine katılmak amacıyla üst düzey bir Sovyet heyeti 26 Ekim-9 Kasım 1933 tarihleri arasını kapsayan bir Türkiye ziyaretinde bulunurlar. Heyette Dışişleri Komiser Yardımcısı L. M. Karahan, Eğitim Komiseri Bubnov, Eğitim Komiser Yardımcısı Krijanovski, SSCB Süvari Kuvvetleri Komutanı ve Devrim Komuta Konseyi Üyesi Budyonni ve Dışişleri ve Savunma komiserliklerinde üst düzey yetkililer katılmışlardır. Heyette ayrıca Sovyet gazeteleri "İzvestiya" ve "Pravda"dan Razevski ile İsakov ${ }^{6}$ ve makalede ele aldığımız "Ankara: Türkiye'nin Kalbi” belgeselinin ekibi de yer almıştır.

Türkiye’nin Sovyetler Birliği ile 1920'ler ve 1930'lar boyunca kurduğu yakın ilişkiler, 1939 tarihli "Alman-Sovyet Saldırmazlık Paktı”nın imzalanması ve sonrasında Türkiye’nin savaşta

\footnotetext{
${ }^{2}$ Mustafa Balcıoğlu, "Direnen Millet - Milli Mücedele: Ya İstiklâl Ya Ölüm”, s. 225-226.

${ }^{3}$ Mustafa Yılmaz, "Yeni Türk Devletinin Dış İlişkileri (1923-1938)", Atatürk ve Türk İnkılâp Tarihi, Ed: Fatma Acun, Ankara: Siyasal Kitabevi, 11. baskı, s. 291.

${ }^{4}$ Mustafa Balcığlu, "Cumhuriyet Dönemi Dış Politikası", Türkiye Cumhuriyeti Tarihi. Cilt:II, Ankara: AKDTYK Atatürk Araştırma Merkezi, 2005, s. 426.

${ }^{5}$ Erik Jan Zürcher, Modernleşen Türkiye’nin Tarihi, Çev. Yasemin Saner Gönen, İstanbul: İletişim Yayınları, 20. baskı, 2006, s. 293-294.

${ }^{6}$ Dimitır Vandov, Atatürk Dönemi Türk-Sovyet İlişkileri, İstanbul: Kaynak Yayınları, 2014, s. 151.
} 
tarafsız kalmasıyla bozulmaya başlamıştır. II. Dünya Savaşı'nın sonunda Sovyetler Birliği, 1945 yılında süresi biten Türk-Sovyet Dostluk Anlaşması'nı yenilemeyeceğini açıklamış ve hemen sonrasında Sovyet Birliği Dışişleri Bakanı Molotov, yeni bir dostluk anlaşmasının imzalanmasından önce yerine getirilmesi gereken bazı koşullardan söz etmiştir. Bu koşullar, 1878-1918 yılları arasında Rus işgalinde bulunan Kars ve Ardahan’ın Sovyetler Birliğìne iadesi, İstanbul Boğazı ve Çanakkale Boğazı bölgesinde Karadeniz’in korunması için ortak bir Türk-Rus savunma gücünün kurulmasını içermekteydi. Sovyetler Birliği’nin bu istekleri 8 Ağustos 1946'da Türkiye’ye resmen bildirildiğinde, ABD’nin de desteğini alan Türkiye, Sovyet isteklerini reddetti. ${ }^{7}$ Stalin'in Türkiye'ye yönelik saldırgan politikaları Türkiye'nin genelde Batı'ya ve özelde Amerika Birleşik Devletleri’ne yakınlaşmasına neden oldu. ${ }^{8}$

\section{Sanat Alanında Yakınlaşma}

Rusya'da 1917 yılında gerçekleştirilen Ekim Devrimi’yle iktidara gelen Bolşevikler, ülkede önceki dönemden kalma köklü bir sanat birikimi bulmuşlardır. Çünkü Çarlık Rusyası; dünyaca tanınan edebiyatçılar, ressamlar ve müzisyenler yetiştirmiş, Avrupa kültür-sanat merkezleriyle yoğun bir iletişim içinde olan bir ülkeydi. ${ }^{9}$ Bolşevik Devrimi sonrasındaki birkaç yıl, Sovyetler Birliğìnde faaliyet gösteren çeşitli sanatçı grupları Komünist Parti’yi desteklemişlerdi. ${ }^{10}$ Ancak Stalin'in iktidara gelişiyle beraber, özellikle 1930'ların başında, Sovyetler Birliğinde var olan bütün sanat akımlarına karşı cephe alınıp Komünist Parti güdümünde bir sanat akımı olan Sosyalist Gerçekçilik, resmi sanat anlayışı olarak benimsendi. ${ }^{11}$ Böylece sanat, hem proleter toplumun yaşantısının konu edildiği, hem de hedef olarak görülen komünist devlet ve toplumun propagandasının yapıldığı gerçek anlamda bir ideolojik aygıt haline geldi. Bu dönemde Sovyet yönetimi tarafından sanatçılar, devlete ve partiye hizmet etmek için örgütlendirilip hangi tür konuları işleyip hangi biçemleri kullanacakları kendilerine dikte edilmiştir. Buna uymayan sanatçılar çeşitli yasaklama, sansür ve sürgün cezalarına çarptırılmışlardır. ${ }^{12} 1932$ yılında resim ve heykel çalışmaları, "Sanatçılar Birliğiı"nin merkezi denetimi altına alınmıştır. ${ }^{13}$ Partinin edebiyat anlayışına uygun kitaplar yazan edebiyatçıların eserleri, Proleter Yazarlar Birliği tarafından basılmıştır. ${ }^{14}$ Komünist Parti, sinemayı da bütünüyle kontrolü altına almış, kendi amaçları doğrultusunda kullanmış ve "Ajitasyon Trenleri”yle ülkenin en ücra köşelerine kadar taşımıştır. ${ }^{15}$

1920'lerin ortalarından itibaren Türkiye'de, yeni kurulan Cumhuriyet'in idarecileri açısından sanat; bir eğitim, kültür ve medeniyet meselesi olarak görülmekteydi. Osmanlı’nın son döneminde kurulan modern okullarda Batılı eğitim görmüş, başta Mustafa Kemal Atatürk olmak

\footnotetext{
${ }^{7}$ Erik Jan Zürcher, Modernleşen Türkiye’nin Tarihi, s. 302-303

${ }^{8}$ Feroz Ahmad, Modern Türkiye’nin Oluşumu, İstanbul: Kaynak Yayınları, 6. baskı, 2007, s. 131.

${ }^{9}$ Hüseyin Elmas, “Ondokuzuncu Yüzyıldan Günümüze Özgürlük Bağlamında Sanat Neydi, Ne Oldu?”, s. 291, http://www.sosyalbil.selcuk.edu.tr/sos_mak/makaleler/H\%C3\%BCseyin\%20ELMAS/ELMAS,\%20 H\%C3\%BCseyin.pdf (01-02-2011).

${ }^{10}$ William H. McNeill, Dünya Tarihi, Çev. Alâeddin Şenel, 5. baskı, Ankara, İmge Kitabevi, 2001, s. 792.

${ }^{11}$ Kürşat Budak, "20. yy. Resim Sanatında Ulusal Eğilimler”, Yüksek Lisans Tezi, Erzurum: Atatürk Üniversitesi Sosyal Bilimler Enstitüsü, Resim Anasanat Dalı, 2008, s. 22.

${ }_{12}$ William H. McNeill, a.g.e., s.792.

${ }^{13}$ John Berger, Sanat ve Devrim, Çev. Bige Berker, İstanbul: Agora Kitaplığı, 2007, s. 37.

${ }^{14}$ Erdoğan Uygur, "Sosyalist Realizm Kavramının Ortaya Çıkış Süreci", Türkiye Sosyal Araştırmalar DergisiTurkish Journal of Social Research, 9(1-2), 23-30, s. 3.

${ }^{15}$ Erdoğan Çiçek, “Günümüzde Devletler Tarafından Uygulanan Psikolojik Operasyonlar Teorisi”, Yüksek Lisans Tezi, Ankara: Kara Harp Okulu Savunma Bilimler Enstitüsü Güvenlik Bilimleri Ana Bilim Dalı, 2006, s. 41.
} 
üzere yeni rejimin seçkin devlet adamı ve bürokratları; sanata, inkılâpları halka benimsetmekte faydalanılacak bir ideoloji aktarım aygıtı olmasının ${ }^{16}$ yanı sıra; toplumu dönüştürücü, eğitim-kültür seviyesini artırıcı, modernleştirici ve yeni bir ulus kimliğinin oluşmasında halkı bilinçlendirici bir araç anlamı da yüklemişlerdir. ${ }^{17}$ Atatürk ve diğer idareciler, çeşitli vesilelerle yaptıkları sanatı ve sanatçııı öven konuşmalarında, sanat alanında bazı kesimlerde görülen "dinsel nitelikli" önyargıların yersizliğine, sanatta ilerlemenin bir medeniyet göstergesi olduğuna ve sanatsal üretimin inkılâpların halka iletilmesi ve benimsetilmesindeki rolü ve önemine değinmişlerdir. ${ }^{18}$ İşte iki ülke arasında siyasal ilişkilerin gelişmesine paralel olarak 1920'lerin ortalarından itibaren sanat alanında da temaslar kurulmaya başlanmıştır. ${ }^{19}$

Cumhuriyet'in 1923 yılındaki ilanından hemen sonra yapılan yasal değişim ve uygulamalarla ülkedeki sanat eğitiminin niteliği yanında niceliğin de artırılmasına çalışılmış ve sanat eğitimi konusunda görüşlerine başvurulmak üzere yabancı uzmanlar ve sanatçılar ülkeye davet edilmişlerdir. ${ }^{20}$ Davet edilen bu yabancı uzmanlara çeşitli alanlarda raporlar hazırlatılmış, yabancı sanatçılara ise, Atatürk ilke ve inkılâplarını temsil edecek anıt heykeller ${ }^{21}$ ve mimari eserler yaptırılmıştır. Profesyonel olarak eser siparişi verilen bu sanatçıların yanı sıra özellikle Nazi Almanyası'ndan kaçan bazı sanatçılar da, yine bilgi ve birikimlerinden yararlanmak amacıyla Türkiye’ye davet edilmiş, söz konusu sanatkârların Güzel Sanatlar Akademisi ve üniversitelerin sanat bölümlerinde ders vermeleri sağlanmıştır. ${ }^{22}$ Heykel alanında daha fazla İtalyan, Avusturyalı ve Alman sanatçılardan; müzik alanında Macar ve Sovyet sanatçılardan; sinema alanında o dönemde bu alanda çok ileride olan Sovyet sanatçılardan; Mimari ve şehir planlama alanlarında ise Fransız ve Alman uzmanlardan yararlanılmıştır. ${ }^{23}$ Yetenekli öğrenciler eğitim için genellikle Fransa ve Almanya’ya gönderilmişlerdir. ${ }^{24}$

\section{Resim}

1930’larda Türkiye ile Sovyetler Birliği arasında, siyasal ve ekonomik alanda gelişen ilişkilere paralel olarak sanat alanında da görülen etkileşimin önemli göstergelerinden biri de resim konusundaki faaliyetlerdir. Sovyet Ressam Kiriçenko, 1930 yılında Türkiye’ye gelmiş, Türk

\footnotetext{
${ }^{16}$ Nezihe Şentürk, “Atatürk’ün Özdeyişlerinde Kültür Sanat Müzik Yaklaşımı”, Uluslararası Atatürk ve Güzel Sanatlar Sempozyumu Bildirileri, Haz. Nail Tan, Hayrettin İvgin, Ankara: 26-27 Ekim 2001, s. 105.

${ }^{17}$ Atatürk’ün Söylev ve Demeçleri (sadeleştirilmiş metin), 22 Ocak 1923, Bursa Şark Sineması, http://www. atam.gov.tr/index.php?Page=Print\&SoylevDemecIcerikNo=134\&Yer=NutukIcerik (11-03-2012). Orijinal metin için: Atatürk'ün Söylev ve Demeçleri II, 5. baskı, Ankara: ADTYK Atatürk Araştırma Merkezi Yayınlar1, 1997, s. 71.

${ }^{18}$ Düşünceleriyle Atatürk, 3. baskı, Arı İnan (Der.), Sadeleştiren: İsmet Parmaksızoğlu, Ankara: AKDTYK Türk Tarih Kurumu Yayınları, 1999, s. 144.

${ }^{19}$ Dimitir Vandov, a.g.e, s. 259.

${ }^{20}$ Lale Altınkurt, “Türkiye’de Sanat Eğitiminin Gelişimi”, s. 3, http://sbe.dpu.edu.tr/12/125-136.pdf (15-022011). Esen Karadağ, “Cumhuriyet Dönemi Kadın Sanatçıların Resim Öğretimindeki Rolü”, Yüksek Lisans Tezi, Samsun: Ondokuzmayıs Üniversitesi Sosyal Bilimler Enstitüsü Güzel Sanatlar Eğitimi Anabilim Dalı, 2008, s. 39.

${ }^{21}$ Murat Özgür, “Güneydoğu Anaolu Bölgesi’ndeki Atatürk Anıtları”, Yüksek Lisans Tezi, Van: Yüzüncü Yıl Üniversitesi Sosyal Bilimler Enstitüsü Sanat Tarihi Anabilim Dalı Genel Sanat Tarihi Bilim Dalı, 2005, s. 2527.

${ }^{22}$ Seda Bayındır Uluskan, Atatürk’ün Sosyal ve Kültürel Politikaları, Ankara: AKDTYK Atatürk Araştırma Merkezi, 2010, s. 522. Sezer Tansuğ, Çağdaş Türk Sanatı, 4. baskı, İstanbul: Remzi Kitabevi, 1996, s. 191-193.

${ }^{23}$ Ömer Turan, “1930'lardaki 'Şehircilik Tartışmaları' Cumhuriyetin Kamusal Alanını Oluşturması”, Toplumsal Tarih, XV(85), 2001, s. 53.

${ }^{24}$ Hüseyin Gezer, Cumhuriyet Dönemi Türk Heykeli, 3. baskı, Ankara: Türkiye İş Bankası Kültür Yayınları, 1984, s. 15.
} 
Ressam Abidin Dino ise Sovyetler Birliği’ne davet edilmiştir. Kiriçenko, İstanbul'da Güzel Sanatlar Akademisi’nde genç ressamların eğitmenlerinden olan dönemin ünlü Türk ressamı İbrahim Çallı'yla birkaç ay beraber çalışmıştır. ${ }^{25} 31$ Mart 1934 tarihli "Cumhuriyet" gazetesinin haberine göre, "Ankara: Türkiye’nin Kalbi” filminin yönetmeni Yutkeviç, çekimler için Türkiye’de bulunduğu sırada görüp beğendiği D Grubu’na bağlı ressamların eserlerinin Moskova'da sergilenmesi için girişimde bulunmuştur. Bunun sonucunda aralarında Abidin Dino ve Fikret Mualla’nın da bulunduğu bir grup Türk ressamın eserleri Moskova ve Leningrad'daki Sanatkârlar Kulübü’nde sergilenmiştir. ${ }^{26}$

2 Ocak 1936 tarihli "Cumhuriyet" gazetesinin haberine göre ise, 1 Ocak tarihinde Rusya Güzel Sanatlar İşçileri Kooperatif Birliği’nin atölyesinde ilk Türk resim sergisi açılmıştır. Açılış töreninde Sovyetler Birliği Kültür Bakanı Bubnof, Türkiye’nin Moskova Büyükelçiliği görevlileri ve diğer yetkililer de hazır bulunmuşlardır. Serginin açılış konuşmasını SSCB Dış Ülkelerle Kültürel İlişkiler Kurumu (VOKS) direktörü yapmış, İstanbul milletvekili Salâh Cimcoz da, Türk ressamlara gösterdikleri ilgiden dolayı Rus hükümetine teşekkür etmiştir. ${ }^{27}$ Aynı gazetenin 20 Ocak 1936 tarihli haberinde ise, Türk ressamların Moskova’da açtıkları bu resim sergisini üç haftada on iki bin kişinin ziyaret etmiş olduğu ve sergiden memnun kalan Ukrayna ve Kafkas hükümetlerinden yetkililerin serginin, Kiev ve Tiflis'te de tekrarlanmas1nı istedikleri ifade edilmiştir. ${ }^{28}$

\section{Tiyatro}

Türk sanatçıların ve yazarların tiyatro alanında ilgiyle takip ettikleri ülkelerden biri de Sovyetler Birliğidir. Muhsin Ertuğrul 1925 yılındaki Sovyetler Birliği seyahatinde sinema ile birlikte tiyatro alanında da gözlemlerde bulunmuş ve dönüşünde Darülbedayỉnin yeniden örgütlenmesinde buradaki tecrübelerinden faydalanmıştır. 1934 yılında yeniden Sovyetler Birliği’ne giden Ertuğrul, Stanislavski gibi önemli Sovyet sanatçıların çalışmalarını takip etmiş ve onların tecrübelerinden yararlanmıştır. ${ }^{29}$ Ertuğrul, ayrıca Sovyet tiyatrocu Meyerhold'un artistleri hazırlama ve yönetme alanındaki başarılarını takdir ettiğini belirtmiştir. ${ }^{30}$ Dönemin Türk basınında da Sovyet tiyatrosu hakkında yazılar yayınlanmıştır. 1934 yılında "Yeni Adam" dergisinde yayınlanan makalesinde Paul Gsell, Sovyet liderleri “...tiyatroyu cemiyetlik propaganda aleti ve vasıtası telakki ettiklerinden, gösterilen mevzular yeni ve ihtilâlcı görüşlere mutaalıktır." demektedir. Gsell ayrıca, Moskova'da profesyonellerin oynadıkları bütün tiyatroların devlete ve özellikle Eğitim Bakanlığı komiserliğine bağlı olduğunu ve tiyatro repertuarının propaganda ihtiyaçlarına göre şekillendiğini belirtmektedir. ${ }^{31}$ Sanatçı ve Yazar Münir Hayri ise, 1935 yılında “Ülkü” dergisindeki bir yazısında gezici tiyatrolar konusunda Faşist İtalya ve Sovyet Rusya’nın dikkate değer çalışmaları olduğunu belirtmiştir. ${ }^{32}$

\section{Müzik}

Bu yıllarda Sovyetler Birliği ile sanat alanında geliştirilen işbirliği müzik alanında da kendini

\footnotetext{
${ }^{25}$ Dimitır Vandov, a.g.e, s. 270.

26 "D grupu ressamları", Cumhuriyet, 31 Mart 1934, s. 2.

27 "Moskovada Türk resim sergisi", Cumhuriyet, 2 İkincikanun (Ocak) 1936, s. 1.

28 "Moskovadaki Türk resim sergisi", Cumhuriyet, 20 İkincikanun (Ocak) 1936, s. 9.

${ }^{29}$ Mahad Sofiev Mahmudoğlu, “Sovyet Kültürünün Türkiye Üstündeki Olumlu Etkileri”, Toplumsal Tarih, VIII(48), 1997, s. 34.

${ }^{30}$ Dimitır Vandov, a.g.e, s. 272.

${ }^{31}$ Paul Gsell, "Sovyet Memleketinde Tiyatro", Yeni Adam, 25 Haziran 1934, s. 6, 12.

${ }^{32}$ Münir Hayri, “Gezgin Tiyatrolar”, VI(34), 1935, s. 314-315.
} 
gösterir. Öyle ki, Atatürk'ün yapmak istediği “müzik inkılabı”na destek olmak için VOKS’da özel bir komisyon kurulur. Bu komisyona Sovyet Besteciler Birliği, Radyo Komitesi, Moskova Konservatuarı, Bolşoy Tiyatrosu ve Baş Musiki Basımevi’nden temsilciler katılır. ${ }^{33} 1933$ yılında Türk hükümetinin davetiyle ünlü Sovyet tenor Smirnov Türkiye’yi ziyaret eder. 1935 yılının Nisan ve Mayıs aylarında ise Sovyetlerin meşhur Bolşoy Tiyatrosu'na mensup büyük bir grup Türkiye'yi ziyaret eder. Heyette ünlü besteci Şoştakoviç de vardır. ${ }^{34} 1$ Mayıs 1935 tarihli "Tan" gazetesinde Sovyet sanatçılar tarafından Ankara Halkevi’nde bir konser verildiğini ve başbakanın, dahiliye bakanının ve hariciye bakanının konseri takip ettikleri belirtilmiştir. ${ }^{35}$ Türkiye'yi ziyaret eden bu Sovyet ses sanatçılarından Barsana’nın, ülkesine dönmeden hemen önce kullandığı, "Yeni kültür Türkiyesine gelmek ruhumda ve kalbimde unutulmaz bir hatıra bıraktı. Türkiye’nin musiki devrimi zamanında sanatımızı dost Türkiye halkına gösterecek fırsatı elde ettiğimizden çok memnunuz." ${ }^{36}$ ifadeleri Sovyet sanatçıların Türkiye'deki müzik inkılabına ilgilerini göstermektedir. Moskova Akademi Tiyatrosu Müdürü Arkanov ise, Atatürk ve İnönünün kendilerine gösterdikleri ilgiden dolayı mutluluk duyduklarını söyledikten sonra Türkiye'de oluşturulmak istenen milli musiki konusunda kullandığı, "Yeni musikinin kuruluşunda halk musikisini temel olarak alıyorsunuz. Bu gayet doğrudur. Biz de böyle yaptık ve muvaffak olduk." ${ }^{37}$ ifadeleriyle Türk devletinin müzik konusundaki tutumunu doğru bulduğunu belirtmektedir. Konservatuar Müdürü Yusuf Ziya Bey ise, "Halkın hislerini sanatlaştırmak meselesi Sovyet dostlarımızın tuttuğu bir yoldur. Onlar da köylü danslarını, havalarını topladılar. Biz de uzun zamandan beri aynı yolu tutmuş bulunuyoruz." ${ }^{38}$ ifadeleriyle müzik alanında Sovyet uygulamasıyla Türk uygulamasının paralel olduğunu vurgulamaktadır.

Sovyet müzisyenlerle kurulan ilişki sonraki yıllarda da devam eder. 26 Haziran 1940 tarihinde Maarif Vekili Hasan Âli Yücel, Yüksek Başvekalet’e gönderdiği tezkerede İstanbul Öğretmen Okulu keman öğretmeni Ekrem Zeki Üngör'ün Moskova’daki VOKS kurumuna "Peşrev" adlı eserini göndermek istediğini belirtmekte ve bu hususta bir mahzur olup olmadığının Maarif Vekilliği’ne bildirilmesini istemektedir. ${ }^{39}$ Başvekalet, 2 Temmuz 1940 tarihinde Maarif Vekaleti’ne yazdığı cevabi yazıda, Ekrem Zeki Üngör'ün “Peşrev” adlı eserini VOKS’a göndermesinde bir mahzur olmadığını bildirmiştir. ${ }^{40}$

\section{Edebiyat}

1930’larda Türkiye ile Sovyetler Birliği arasında edebiyat alanında da bir etkileşimden söz etmek mümkündür. Türk hükümeti özellikle Sovyetler'deki örgün eğitim ve halk eğitimi alanında neler yapıldığını bilmek istemekte, bunun için VOKS’an bilgi istenmekte ${ }^{41}$ ya da Türkiye’nin Moskova büyükelçisi gözlemlerini, Türk Dışişleri Bakanlığı’na rapor olarak gön-

\footnotetext{
${ }^{33}$ Mahad Sofiev Mahmudoğlu, a.g.m., s. 35.

${ }^{34}$ Dimitır Vandov, a.g.e, s. 264-65.

35 "Sovyet Artistlerinin Konseri", Tan, 1 Mayis 1935, s. 3.

36 "Sovyet Artistleri Memleketlerine Döndüler", Tan, 17 Mayıs 1935, s. 11.

37 "Sovyet Artistleri Memleketlerine Döndüler", Tan, 17 Mayıs 1935, s. 11.

38 "Sovyet Artistleri Memleketlerine Döndüler", Tan, 17 Mayıs 1935, s. 11.

${ }^{39}$ Maarif Vekili Hasan Âli Yücel’in 26 Haziran 1940 tarihinde Yüksek Başvekalet’e gönderdiği tezkere için bkz. BCA, 030.10-146-44-11, s. 2.

${ }^{40}$ Başvekalet'in 2 Temmuz 1940 tarihinde Maarif Vekaleti’ne yazdığı cevabi yazı için bkz. BCA, 030.10-146-4411, s. 1

${ }^{41}$ Mahad Sofiev Mahmudoğlu, a.g.m., s. 31.
} 
dermektedir. ${ }^{42}$ İşte bu ortamda önemli Sovyet yazarı Maksim Gorki, Cenova'daki tedavisinden sonra Sovyetler'e dönerken 15 Mayıs 1933 tarihinde İstanbul'a uğramış, 17 Ağustos 1934 tarihinde ise Türk edebiyatçı ve yazarlar Falih Rıfkı (Atay) ve Yakup Kadri (Karaosmanoğlu), Moskova'da toplanan Sovyet Yazarlar Kongresi'ne katılmışlardır. ${ }^{43}$ Kurultaydan sonra Sovyet yazar İlya Grigoryeviç Ehrenburg İstanbul'a gelmiştir. Basın müdürü Neşet Nail tarafından karşılanan Ehrenburg, Falih Rıfkı, Yakup Kadri ve diğer bazı Türk yazarlarla edebiyat alanında işbirliği yapılması konusunda görüşmelerde bulunmuştur. ${ }^{44}$ Bahsedilen dönemde Türkiye'de bir edebiyat kanonu oluşturulması için pratik, teorik ve manipülatif çabalar gösterilmesiyle, Sovyetler Birliği’ndeki parti edebiyatı arayışlarının aynı döneme denk gelmesini, Sovyetler'deki sosyalist sanat politikalarının Türkiye'ye rehber olduğu şeklinde yorumlayan yazarlar olmuştur. ${ }^{45}$

Sovyetler, bu dönemde Türkiye’ye çeşitli alanlarda yazılmış kitaplar da göndermişlerdir. Niyazi Berkes, 1930’ların başında Ankara Halkevi’nde çalışırken Halkevleri Başkanı Necip Ali (Küçüka) kendisini telefonla odasına çağırır ve ona, "Şu Bolşevikler ne inatçı kişiler. İlle bizi de komünist yapacaklar." deyip odanın bir köşesindeki kitapları göstererek, "Yine sefaretten bir alay kitap hediye ettiler. Şimdi ne yapalım? Geri çevirsek olmaz, ayıp olur. Kitaplığa koysak olmaz. Hade... sen bu kitapları âââal, bir köşeye koy. Kayda geçirme. Öyle dursun. İstersen sen kendin al, oku. Kötü şeyler değil. Shakespeare, Gogol, Tolstoy, Turgenief, hatta bizim Reşat Nuri bile var. Hepsi Türkçe. Bu yapitlar bizde bile Türkçeye çevrili değil. Ama hepsi ya Azeri ya da Kazan Türkçesi. Yalnız hınzırlar araya bir adet Marx ile bir tane de Lenin koymuşlar. Tam külliyatları bile değil." dediğini aktarır. Necip Ali, konuşmasını Berkes’e "Pek alâ, sen bunları ââââal, odanda bir köşeye koy, onlardan biri gelirse henüz kaydedilme sıraları gelmedi de, olur mu?” diyerek sürdürür. ${ }^{46}$ Örnekte de görüldüğü üzere, Sovyetler edebiyat yoluyla kendi ideolojilerinin propagandasını yapmak için çaba sarf ederken, Türk yetkililer hem ilişkilerin bozulmamasına hem de bu propagandadan fazla etkilenmemeye çalışmaktadırlar.

\section{Sovyet Sineması ve Türkiye}

1920'li ve 1930'lu yıllar Sovyetler Birliği’nde, sinemanın son derece gelişme gösterdiği yıllardır. Sovyet sinemacılar bu dönemde ürettikleri filmler ve sinema kuramlarıyla dünya sinemasını ciddi bir şekilde etkilemişlerdir. ${ }^{47}$ İşte bu dönemde Türkiye, yine kendisi gibi bir tek parti iktidarı tarafından yönetilen Sovyetler Birliği’nin sinema tecrübesinden yararlanmak istemiştir. Türk seyircilerinin Sovyet filmleriyle 1926 yılından itibaren tanışmaya başladığ 1 bilinmektedir. Sovyetler Birliği’nden Türkiye’ye gelecek filmler ilk önce Moskova’daki Türk Büyükelçiliği yetkilileri tarafından incelenmiştir. Türk makamları, Cumhuriyet rejimine aykırı propaganda nitelikli Sovyet filmlerinin Türkiye'de gösterilmemesi için böyle bir uygulama yapmışlardır. ${ }^{48}$ Türk Büyükelçiliği'ni ziyaret eden Sovyet yetkilileri de, kendi filmlerindeki yazıların istenilen şekilde tercüme edilebileceğini, üzerlerinde değişiklik yapılabileceğini ve dolayısıyla filmlerin her türlü ön denetimden geçirilebileceğini Türk Büyükelçiliğine

\footnotetext{
${ }^{42}$ Mahad Sofiev Mahmudoğlu, a.g.m., s. 37-38.

${ }^{43}$ Mahad Sofiev Mahmudoğlu, a.g.m., s. 34.

${ }^{44}$ Dimitır Vandov, a.g.e, s. 260.

${ }^{45}$ Ömer Türkeş, “Güdük Bir Edebiyat Kanonu”, Modern Türkiye’de Siyasî Düşünce, Cilt:II, Kemalizm, 6. baskı, İstanbul: İletişim Yayınları, 2009, s. 425.

${ }^{46}$ Niyazi Berkes, Unutulan Yillar, İstanbul: İletişim Yayınları, 1997, s. 79.

${ }^{47}$ Riza Oylum, Rus Sineması, İstanbul: Başka Yerler, 2011, s. 14.

${ }^{48}$ Raşid Tacibayev, Kızıl Meydan'dan Taksime, İstanbul: Truva Yayınları, 2004, s. 190.
} 
bildirmişlerdir. ${ }^{49}$ Görülüyor ki, Sovyet yetkililer de filmlerinin Türkiye'de gösterilmesi konusunda oldukça isteklidirler.

Bu dönemde Türk sinemacıların, Sovyet sinemacıların deneyimlerinden faydalanmak için Sovyetler Birliği’ne gittikleri de görülür. 1925 yılında Sovyetler Birliği’ne giden Muhsin Ertuğrul, burada Sovyetler'in Eğitim Komiseri Lunaçarski'yle görüşmüş ve ona Sovyetler'in sinema ve tiyatro alanında attıkları yenilikçi adımları izlemek istediğini söylemiştir. Ertuğrul, burada Eisenstein gibi önemli yönetmenlerle de tanışmış ve Odesa'daki Sinema Fabrikası Vufku’ya giderek burada "Tamilla" ve "Spartaküs" adlarında iki film yönetmiştir. ${ }^{50} \mathrm{Bu}$ yıllarda Ressam Abidin Dino ve Şair Nazım Hikmet' in de Sovyetler'de bulundukları dönemde sinemayla ilgilendiklerini görürüz. Abidin Dino, Sovyet yönetmenler Yutkeviç ve Eisenstein'le bir süre beraber çalışmıştır. ${ }^{51} 1926$ yılında Moskova’ya giden Türk sinema sanatçısı Münire Mint (Neyyire Neyir), İstanbul dönüşünde, "Bütün dünyanın en güzel bedii sanat merkezi olan Moskova’ya yaptığım geziden büyülenerek ve şükranla döndüm." demiştir. ${ }^{52}$ Görülüyor ki, Türk yönetmen ve sinema oyuncuları, Sovyetler'in sinema alanındaki çalışmalarından haberdardırlar ve bunu yerinde görmek için Moskova’ya gitmektedirler. 20 Şubat 1935 tarihinde, Reisicumhur Atatürk’ün imzasıyla, Burhan Toprak’n Sovyet sinemasının kuruluş yıldönümü etkinliklerinde Türkiye’yi temsil için Sovyetler Birliği’ne gönderilmesi yönündeki kararname imzalanır. ${ }^{53}$

27 Haziran 1926 tarihinde Türkiye’nin Moskova Büyükelçiliği’nden gönderilen bir yazıda, Türk ve Sovyet filmlerinden on tanesinin karşılıklı değişimi konu edilir. Moskova’daki Türk Büyükelçiliği filmleri görür ve Dâhiliye Vekâleti’ne bu filmler hakkında ayrıntılı bilgi arz eder. Türk Büyükelçiliği’nin incelediği bu filmlerden birisi, “ilerleme" ve "gerilik" kurgusu üzerine oturtulmuştur. Filmde, Sovyetler Birliği’nde inşa edilen binalar ve Sovyet şehirlerindeki sağlıkla ilgili çalışmalar, ilerlemeyi temsil etmektedir; Sovyet köylerinde batıl inançlar nedeniyle yapılan yanlıs tedavi uygulamaları ile ilgili sahneler ise geriliğin göstergesi olarak sunulur. Gönderilen yazıda, bu filmin Türkiye’nin değişik yerlerinde yaşayan vatandaşları, bu konularda aydınlatacağı vurgulanır ve filmin, "Himaye-i Etfal Cemiyeti”nde gösterilmesi özellikle tavsiye edilir. ${ }^{54} 1935$ yılında Sovyetler Birliği’nden İstanbul Belediyesi’ne sütçülük ve süt hayvancılığı hakkında hazırlanmış öğretici filmler gönderilmiştir. Bu filmlerde, inek bakımı, süt sağımı ve dağıtımı konusunda bilgi verilmektedir. Belediye, filmi mensuplarının eğitiminde kullanması amacıyla Sütçüler ve İnekçiler Cemiyeti’ne teslim etmiştir. ${ }^{55}$

\section{3-1933 yılları Arasında Yeni Başkent Ankara’nın Görüntüsü}

Büyük Millet Meclisi’nin açıldığı 1920 yılında Ankara, kale içerisinde ve yakın çevresinde kümelenmiş evlerin oluşturduğu, "sıtma yuvası" diye tarif edilen bataklıkların bulunduğu, susuzluk sorunu olan, sert iklimli ve yaklaşık kırk bin kişinin yaşadığı bir şehirdi. ${ }^{56}$ Ancak

\footnotetext{
${ }^{49}$ Serdar Öztürk, Erken Cumhuriyet Döneminde Sinema Seyir Siyaset, Ankara: Elips Kitap, 2005, s. 39.

${ }^{50}$ Gökhan Akçura, Doğumunun Yüzüncü Yılına Armağan: Muhsin Ertuğrul, İstanbul: Kültür İşleri Daire Başkanlığı Yayınları, 1992, s. 16-17.

${ }^{51}$ Dimitır Vandov, a.g.e, s. 273.

${ }^{52}$ Mahad Sofiev Mahmudoğlu, a.g.m., s. 35.

${ }^{53}$ Burhan Toprak’a siyasî pasaport verilmesine dair 20 Şubat 1935 tarihli İcra Vekilleri Heyeti kararı için bkz. BCA, 030.18-01-02-52-11-16.

${ }^{54}$ Serdar Öztürk, a.g.e., s. 37.

55 "Sütçülük için bir film", Tan, 18 Haziran 1935, s. 2.

${ }^{56}$ Kıvanç Kılınç, “Öncü Halk Sağlığı Projelerinin Kamusal Mekânı Olarak Sıhhiye”, Ankara’nın Kamusal Yüzleri, Der. Güven Arif Sargın, İstanbul: İletişim Yayınları, 2002, s. 120.
} 
Milli Mücadele'nin idare merkezi olan Ankara, 13 Ekim 1923 tarihinde, Meclis'in büyük çoğunlukla aldığı kararla başkent olarak kabul edildi. Bu karar, 24 Nisan 1924 tarihinde kabul edilen yeni Anayasa’nın 2. maddesinde de yer almıştır. ${ }^{57}$ Ankara'nın başkent olmasında, demiryolu ağına bağlı olması, telgrafla haberleşme imkânına sahip olması ve Anadolu'nun ortasında dış müdahalelere karşı güvenli bir yerde bulunması gibi gerekçeler yanında, bu seçimde Ankaralıların Milli Mücadele’ye gönülden bağlanmalarının da rolü olduğu vurgulanmaktadır. ${ }^{58}$

Osmanlı’nın merkezi İstanbul'dan sonra yeni başkent olarak kabul edilen Ankara’nın modern bir kent haline getirilmesi, tek parti iktidarı için bir prestij meselesiydi. Bir anlamda Cumhuriyet rejiminin başarısı ile Ankara’nın şehir planlamasında gösterilecek başarı özdeşleşmiş bulunuyordu. 1930'lu yıllardan sonra, Anadolu'da devletin sanayi kurduğu kentlerin ve diğer önemli yerleşim yerlerinin, Ankara’da geliştirilmekte olan modele uygun olarak, modern bir yapıya kavuşturulmasına çalışılmıştır. ${ }^{99}$ Batuman, diğer birçok alanda olduğu gibi şehir planlama alanında da Batı tarzı bir modernleşme isteğinde olan siyasal iktidarın, mevcut kentsel mekanların modernleşmeye karşı bir direnç oluşturma potansiyeli taşıdıklarını gördüğü için, Ankara'da yepyeni bir kent kurma çabası içine girmesini anlamlı bir tercih olarak nitelendirmektedir. ${ }^{60}$ Bu koşullar altında 1923-1950 yılları arasında sosyal, ekonomik ve kültürel gelişmelere paralel olarak, Ankara'daki şehirleşme çalışmaları kimi zaman ulusal, kimi zaman evrensel akımların etkisi altında yoğun bir biçimde sürüp gitmiştir. ${ }^{61}$

Arlı'ya göre, Cumhuriyet'in 1923 yılında kurulmasından 1950 yılına kadar, dönemin siyasal iktidarı tarafından, şehirleşmenin ana mecrasını belirleyen bazı devrimci stratejiler uygulamaya konulmuştur. Osmanlı Devleti'nin başkenti olan İstanbul, modern bir toplumsal mekânın oluşturulması amacı açısından, yeni siyasî elitler tarafından kurumsal ve örgütsel bakımdan "eski”nin sembolü olarak kodlanmıştı. Siyasî elitler, sosyal değişime dönük amaçlarını gerçekleştirebilmek için, "eski” nin sembollerinden uzak, "tabula rasa" bir mekân olarak "bozkırın ortasındaki” Ankara’yı seçmiş ve burayı başkent yapmışlardır. ${ }^{62}$ Cumhuriyet rejiminin simgesi olan Ankara'nın, modern şehircilik anlayışına uygun olarak şekillendirilmesi için 1924 yılında "Ankara Şehremaneti Kanunu" çıkarılarak, bayındırlık faaliyetleri hızlandırılmıştır. 22 Mayıs 1926 tarihinde Emlak ve Eytam Bankası’nın kurulması da önemli bir adımdır; çünkü bu bankanın kredi ve Kaynakçaının ve fonlarının büyük kısmı Ankara’nın imarına ayrılmıştır. 1928 yılında ise "Ankara Şehri İmar Müdürlüğü Teşkilatı" kurulmuştur. Bu müdürlük, Ankara Şehremaneti’ne değil doğrudan Dâhiliye Vekâleti’ne, yani merkezi hükümete bağlıydı. ${ }^{63}$ Böyle yapılarak muhtemelen daha etkili ve hızlı hareket edilmek istenmiştir.

\footnotetext{
${ }^{57}$ Bilal Şimşir, Ankara... Ankara Bir Başkentin Doğuşu, Ankara: Bilgi Yayınevi, 1988, s. 242-243.

${ }^{58}$ L. Funda Şenol Cantek, "Yaban"lar ve Yerliler Başkent Olma Sürecinde Ankara, İstanbul: İletișim Yayınları, 2003, s. 83.

${ }^{59}$ İlhan Tekeli, “Cumhuriyetin Çağdaşlaşma Projesinin Mekansal Boyutu Üzerine Bir Değerlendirme”, Ankara, V. Türk Kültürü Kongresi: Cumhuriyetten Günümüze Türk Kültürünün Dünü, Bugünü ve Geleceği, 17-21 Aralık 2002; Mimari ve Çevre Kültürü, Cilt:VIII, Haz. Azize Aktaş Yasa, Ankara: Atatürk Kültür Merkezi Yayınları, 2005, s. 14-15.

${ }^{60}$ Bülent Batuman, "Mekân, Kimlik ve Sosyal Çatışma: Cumhuriyet’in Kamusal Mekânı Olarak Kızılay Meydanı", Ankara’nın Kamusal Yüzleri, Der. Güven Arif Sargın, İstanbul: İletişim Yayınları, 2002, s. 43.

${ }^{61}$ Ayla Ödekan, "Mimarlık ve Sanat Tarihi”, Türkiye Tarihi, Cilt:IV, Çağdaş Türkiye 1908-1980, Yay. Yön.: Sina Akşin, 9. baskı, İstanbul: Cem Yayınevi, 2007, s. 542.

${ }^{62}$ Alim Arlı, "Cumhuriyet Döneminde Türkiye'de Şehirleşme ve Gecekondu Araştırmaları", Türkiye Araştırmaları Literatür Dergisi, III(6), 2005, s. 292.

${ }^{63}$ Ömer Turan, a.g.m., s. 54.
} 
Ankara’nın şehir planlarını yaptırmak üzere H. Jansen, M. Briy ve L. Jausseley adlı yabancı uzmanlar ülkeye davet edilerek 1927 yılında "Ankara İmar Planı Yarışması" düzenlenmiştir. Yarışmayı Mimar H. Jansen kazanmıştır. ${ }^{64} \mathrm{H}$. Jansen'in Ankara'daki uygulamadan imar mevzuat1, örgütlenme, imar yolsuzluğu, arsa spekülasyonu gibi çeşitli konulardaki görüş ve çalışmalarından, sonraki yıllardaki çalışmalarda da yararlanılmıştır. ${ }^{65}$ Önerdiği plan ancak 23.7.1932 tarihinde uygulamaya giren Mimar H. Jansen’i Atatürk'le tanıştıran Falih Rıfkı Atay, Mimar Jansen ile Atatürk arasında geçen konuşmayı şöyle nakletmiştir: Alman Mimar Jansen, Mustafa Kemal Atatürke "Bir şehir planını tatbik edecek kadar kuvvetli bir iradeniz var mıdır?" sorusunu yöneltmiştir. Atatürk, buna cevaben, "Ne tuhaf bir adam bu. Bizim yaptığımız işler arasında plan tatbiki de nedir?” diye karşılık vermiştir. ${ }^{66}$

Şehirlerin, kasabaların ve hatta köylerin planlamasının yapıldığı, yeşil alanların düzenlendiği, işçi evleri, memur lojmanlarının yapıldığı 1930’lu yıllarda, önemli bir şehircilik ve mimarlık projesi de Ankara’daki ilk büyük ölçekli konut kooperatifi uygulaması olan "bahçeli evler" çalışmasıdır. Ankara'daki bu "bahçeli evler" uygulaması, ülkenin diğer şehirleri için yapılan planlarda da önerilmiştir. ${ }^{67}$ Tekeli'ye göre, bu öneri ve uygulamalar, Batı'da gelişmiş olan "Bahçe Kent" ütopyasının Türkiyedeki yansımasını göstermektedir. ${ }^{68}$

Cumhuriyet'in ilanıyla beraber devletin, sanat etkinlikleri açısından da Ankara’yı ön plana çıkarmak istediği görülür. Bu amaçla önceki dönemde her yıl İstanbul'da Galatasaray Lisesi'nde açılan Sanayi-i Nefise Sergileri'nin, artık Ankara'da açılması için 1926 yılında yasa çıkarılır. ${ }^{69}$ Cumhuriyet'in ilanından hemen sonra Mustafa Kemal Paşa, Osmanlı sarayının Muzıka-i Hümayun Orkestrası'nı Ankara’ya davet etmiştir. Bu davete icabet eden Mızıka-i Humayun, "İstiklal Marşı”nın da bestecisi olan Zeki Üngör’ün yönetiminde 150 kişilik heyeti ve bütün levazımatıyla gelmiş ve Ankara İstasyonu'nun ambarlarından birinin alt katına yerleşmiştir. ${ }^{70}$ Mızıka-i Hümayun, burada 1924 yılında Riyaset-i Cumhur Musiki Heyeti adını alarak düzenli konser $\neg$ ler vermeye başlamıştır. Daha sonra da Riyaset-i Cumhur Filarmoni Orkestrası ve Cumhurbaşkanlığı Senfoni Orkestrası adını alarak Türkiye'de Batı müziğinin gelişimine büyük bir katkı sağlamıştır. ${ }^{71}$

1930-1940 yılları arasında Türkiye'de etkili olan "Uluslararası Mimarlık Akımı” çerçevesinde yabancı mimarlar tarafından Ankara'da çok sayıda bina inşa edilmiştir. Bu kapsamda Ernst Egli, Sayıştay Binası’nı (1928-1930); Clements Holzmeister, Milli Savunma Bakanlı̆̆ı Binası'nı (1928-1930), Genelkurmay Başkanlığı Binası’nı (1929-1930), Ankara Orduevi’ni (1930-1933), Cumhurbaşkanlı̆̆1 Köşkü’nü (1931-1932) ve Yargıtay Binası’nı (1933-1934); Bruno Taut ise Ankara Dil ve Tarih-Coğrafya Fakültesi'ni (1937) inşa etmişlerdir. ${ }^{72}$ Ankara, bir taraftan modern bir şehir görünümüne kavuşturulmaya çalışılırken bir taraftan da Mus-

\footnotetext{
${ }^{64}$ Fehmi Yavuz, “Başkent Ankara ve Jansen”, O.D.T.Ü. Mimarlık Fakültesi Dergisi, Cilt:VII(1), 1981, s. 26.

${ }^{65}$ Ayla Ödekan, a.g.m., s. 525.

${ }^{66}$ Fethiye Erbay, Mutlu Erbay, Cumhuriyet Dönemi (1923-1938) Atatürk'ün Sanat Politikası, İstanbul: Boğaziçi Üniversitesi, 2006, s. 140.

${ }^{67}$ Murat Taş, “Osmanlı’dan Günümüze Yapı Üretiminde Mimarlık Meslek Örgütlenmesinin Gelişimi”, Uludă̆ Üniversitesi Mühendislik-Mimarlık Fakültesi Dergisi, VIII(1), 2003, s. 212.

${ }^{68}$ İlhan Tekeli, “Cumhuriyetin Çağdaşlaşma Projesinin Mekansal Boyutu Üzerine Bir Değerlendirme”, s. 15-17.

${ }^{69}$ Ayla Ödekan, a.g.m., s. 555-556.

${ }^{70}$ Sibel Ertekin, “Türk Operasının Gelişim Süreci”, Yüksek Lisans Tezi, Ankara: Başkent Üniversitesi Sosyal Bilimler Enstitüsü Müzik ve Sahne Sanatları Anabilim Dalı Müzik Bilimi Yüksek Lisans Programı, 2007, s. 56.

${ }^{71}$ Mustafa Şahin, Ruşen Duman, “Cumhuriyet'in Yapılanma Sürecinde Müzik Eğitimi”, Çağdaş Türkiye Tarihi Araştırmaları Dergisi, VII(16-17), 2008, s. 262.

${ }^{72}$ Nilüfer Öndin, Cumhuriyet'in Kültür Politikası ve Sanat 1923-1950, İstanbul: İnsanc1l Yayınları, 2003, s. 79.
} 
tafa Kemal Atatürk'ün, önemli yabancı heykeltıraşlara yaptırılan heykelleriyle donatılmıştır. Bu kapsamda, Heinrich Krippel tarafından 1927 yılında Ulus Meydanı Atatürk Anıtı, 1938 yılında Sümerbank Önü Atatürk Anıtı; Pietro Canonica tarafından 1927 yılında Etnografya Müzesi Atlı Atatürk Heykeli, Sıhhiye Zafer Alanı Atatürk Anıtı ve Anton Hanak ile Josef Thorak tarafından 1935 yılında Güven Anıtı yapılır. ${ }^{73}$

\section{“Ankara: Türkiye’nin Kalbi” Belgeseli}

Türk hükümeti tarafından, Cumhuriyet'in ilanının 10. yıl dönümünde, bu tarihi olayı konu edinen bir film hazırlanması için Sovyetler Birliği’nden sinemacılar Türkiye’ye davet edilmiş ve bu çerçevede Sovyet sinemacılar tarafından iki film yapılmıştır. Bu filmlerin ilki, Yönetmen Sergey Yutkevich ve Lev Arnştam’ı 1933 yılında hazırladığı “Ankara: Türkiye’nin Kalbi” adlı filmdir. Sovyet yönetmenlere Türkiye'de Reşat Nuri (Güntekin) ve Fikret Adil yardımcı olmuşlardır. ${ }^{74}$ Yönetmenler, filmde; kendileriyle birlikte Türkiye’ye gelen Sovyet askeri ve sivil heyetinin Türkiye Cumhuriyeti’nin 10. yılı kutlamaları için önce İstanbul'a oradan da Ankara’ya varışlarını, kutlamaları, daha sonra tüm belgesel filmlerde kullanılacak olan Mustafa Kemal Atatürk’ün “10. Yıl Nutku”nu okumasını, Türkiye’nin yeni başkenti Ankara'dan gelişmişlik göstergesi kurumlarını ve Ankaralıların yaşamlarına ait görüntüleri kullanmışlardır. ${ }^{75}$ Türkiye'deki çekimlerden sonra Sovyetler Birliği’ne giden sinemacılar bir süre sonra son şeklini verdikleri filmle beraber Türkiye’ye dönmüşlerdir. 18 Mart 1934 tarihli “Cumhuriyet" gazetesinde, film yapımcılarının Odesa'dan İstanbul'a geldikleri ve buradan da Ankara’ya geçip hazırladıkları filmi Maarif Vekâleti’ne teslim edecekleri haberi verilmiştir. ${ }^{76}$ İkinci film ise film montajcısı Esther Schub’un eldeki belgeleri kullanıp yeniden kurgulayarak oluşturduğu “Türk İnkılabı’nda Terakki Hamleleri” adlı filmidir. Schub, 1934-1937 yılları arasında Ankara, İzmir ve Ödemiş’te çekimler yaparak bu belgeseli hazırlamış ve film 1937 yılında gösterime girmiştir. Bu film, Türkiye’nin Meşrutiyet’ten Cumhuriyet’e kadar geçirdiği başlıca aşamaları, I. Dünya Savaşı’nı, mütareke yıllarını, Mili Mücadele’yi, Cumhuriyet'in kuruluşunu ve diğer önemli gelişmeleri konu edinen ve eski belgesel filmlerinden derlenerek oluşturulmuş kayda değer bir kurgu filmidir. ${ }^{77}$

Yönetmen Sergey Yutkevich ve Lev Arnştam’ın 1933 yılında hazırladı̆̆g “Ankara: Türkiye’nin Kalbi” belgeseli, günümüzde Türkiye Cumhuriyeti Cumhurbaşkanlığ1 resmi internet sitesinde yayınlanmaktadır. Çalışmayı yaparken biz de bu yayını esas aldık. Film o dönemin alışkanlıklarına ve tekniğine uygun olarak çerçeve yazılar ve arkasından gelen görüntülerden oluşmaktadır. Toplamda 55 dakikalık bir kayıt olan filmin, "Ankara: Türkiye’nin Kalbi”" başlıklı bölümü ilk dakikasında "1" rakamının çerçeve yazı olarak perdeye yansımasından sonra 28. dakikada yine çerçeve yazı olarak "son" ifadesinin perdeye gelmesiyle sona erer. "Son” yazısından sonra perdeye “3” rakamının gelmesi, ardından da "Ankara!" isimli diğer bir bölümün başlaması akıllara, eğer "Ankara!" üçüncü bölümse arada yayınlanmayan bir 2. bölümün olabileceği ihtimali getirmektedir. "Ankara: Türkiye’nin Kalbi” aslında sadece

\footnotetext{
${ }^{73}$ Özgür, a.g.t., s. 27.

${ }^{74}$ Dimitir Vandov, a.g.e, s. 274.

${ }^{75}$ Nijat Özön, Karagözden Sinemaya Türk Sineması ve Sorunları, Cilt:II, Ankara: Kitle Yayınları, 1995, s. 286.

76 “'Türkiye’nin kalbi Ankara’ filmi”, Cumhuriyet, 18 Mart 1934, s. 5.

${ }^{77}$ Veli Boztepe, "1960 ve 1980 Askeri Darbelerinin Türk Siyasal Sinemasına Etkileri”, Yuksek Lisans Tezi, İstanbul: Marmara Üniversitesi Sosyal Bilimler Enstitüsü İletişim Bilimleri Anabilim Dalı Radyo Televizyon Bilim Dalı, 2007, s. 95; Esin Berktaş, "1939-1950 Dönemi Türk Sinemasının Ekonomik, Politik, Toplumsal ve Kültürel Yapısı”, Sanatta Yeterlilik Tezi, İstanbul: Mimar Sinan Güzel Sanatlar Üniversitesi Sosyal Bilimler Enstitüsü Sinema-Tv Ana Sanat Dalı Sinema-Tv Programı, 2008, s. 22.
} 
28 dakikalık bir çalışma mıdır? Yoksa 55 dakikalık ya da daha uzun bir filmin sadece bir bölümü müdür? Dahası bu filmin yayınlanmayan arada ikinci bir bölümü daha var mıdır? $\mathrm{Bu}$ sorulara net bir cevap vermek şu an için zordur.

Filmin içeriğine gelecek olursak: Filmin jeneriğinde görevliler şu şekilde sıralanır: Senaryo: L. Arnştam, S. Yutkeviç. Sahneye Koyan: S. Yutkeviç. Rejisör L. Arnştam. Danışman: D. Melnik. Operatörler: J. Martov, V. Rapoport. Ses operatörü: İ. Volk. Türk kompozitörlerin müziği: Zeki, Ekrem Zeki, Cemal Reşid. Leningrad Flarmoni ve Ankara konservatuarı Orkestra ve Koroları.

Filmde çerçeve yazılar ve arkasından gelen hareketli görüntülerin dökümü şu şekildedir: Burada çerçeve yazılar bold olarak yazılmış ve yanlarına parantez içerisinde zaman kodları yazılmıştır. Jenerikten sonra film Prolog (0:47) çerçeve yazısı ile başlar. Hemen arkasından Bakanlar Kurulu Başkanı İsmet Paşa Filmimizin Cumhuriyetin 10. Yılına İthaf Edilen Bir Konuşma Yaptı (0:51) yazılır ancak İsmet Paşảnın konuşmasına dair bir görüntü yoktur. "Hiç konulmamış mıdır; yoksa sonradan çıkarılmış mıdır?" bilinmemektedir. Bunun hemen akabinde perdede 1 (1:05) rakamı görülür. Bundan sonraki çerçeve yazılar, zamanları ve görüntüler aşağıdadır:

Türk halkı 15 yıl önce Anadolu’da bağımsızlık için savaş başlattı (1:07): Perdede geleneksel çoban elbisesi olan kepeneği giyen bir çoban görülür. Çoban sabit bir şekilde durmaktadır, kamera çobanın omzundan üzerine ve elindeki sopasına odaklanmıştır. Arkasından eşekleri ve develeriyle çorak bir arazide yol alan köylüler görülür. Akabinde koyunlar, önceki çoban görüntüsü, çobanın köpeği ve sürü perdeye gelir. Yine bir grup eşek ve yanlarında üç dört köylü yol almaktadırlar. Sonra sırasıyla bakımsız bir kasaba, sokakta çalışan insanlar, küçük bir cami ve eski, sobaları yanan, harabe bir iki katlı cumbalı evler görülür.

Anadolu köyünden... (4:00): Yaşıı bir adam ve eşi görülür... ...Gitti yaşlı gerilla... (4:15): Yaşlı adam eşeğini çeke çeke götürür. Yaşlı eşi de yanındadır. Onların arkasından evden iki çocuk çıkar. Ankara'ya, Anadolu’nun kalbine. Türkiye’nin kalbine... (4:30): Yaşlı köylü, eşeği üzerinde Ankara'ya girer. Herkese selam verir. Cumhuriyetin 10. Yıl Bayramına (4:45): Eşekle yol alan köylü tekrar görülür. Ankara'ya (5:10): Yaşlı köylü, iki üç katla eski evler arasından geçer. Şehirlerden... (5:25): Bir trenin dönen tekerleri görülür. İstanbul'un... (5:32): Trenden el sallayan genç insanlar. Adana'nın... (5:38): Yine trenden el sallayan gençler. Trenin üzerinde ay yıldız vardır.

Sakin... (5:45): Trenin tekerleri ve tren yolu görülür. Sovyet heyetini Ankara'ya getiren tren görülür. Onları tren garında askeri marşlar çalan bir izci bandosu beklemektedir. İzciler gelen heyeti asker selamıyla karşılarlar. İzci bir kız, Rusça olarak heyeti selamlar. Bando marş çalarak sokaktan geçer, halk da onları izler. Eski zamanlardan bu yana... (7:10): Fonda davul zurna sesleri vardır. Yün eğiren yaşlı bir kadın görülür. Eski dönemi temsil eden kağnılarla temsili bir göç gerçekleştirilir. Kağnıları öküz ve mandalar çekerler. Eskiyi temsil eden bu konvoyun yanından modernliğin temsili gibi sunulan bir otomobil geçer. Onların yanında atlı milisler vardır. Ortamda Cumhuriyet'in 10. Yılı'nı kutlamanın coşkusu vardır. Etrafta bayraklar ve balonlar vardır. Bunun akabinde üzerinde Rusça bir ibare ve orak çekiç amblemi bulunan bir anıt görülür.

Sovyetler Birliği’nden dostlar Boğaz’a gittiler. (8:48): İstanbul Boğazı'nda Sovyet heyetini getiren gemiler ve ardından Sovyet heyeti görülür. SSCB Hükümeti Heyeti Başkanı K. E. Voroşilov (9:13): Heyet Başkanı Voroşilov elinde dürbünle boğazı seyretmektedir. Bir 
Türk subay heyet üyeleriyle sohbet ederken görülür. Gemileri, askeri uçaklar alçaktan uçarak takip ederler. Gemideki subaylar ellerindeki şapkalarla bu uçakları selamlarlar. Süvari baş müfettişi S. M. Budennıy (9:51): Bu çerçeve yazıdan sonra görüntü gelmez. Bir önceki görüntüde uçaklara şapka sallayan subay S. M. Budennıy olabilir.

Türk hükümetinin temsilcileri konuklarını İzmir limanında karşıladılar. (9:56): Fonda İstiklal Marşı çalınır. İzmir limanında küçük teknelerle Sovyet heyetini karşılamaya gelenlerin görüntüleri perdeye gelir. Uçaklar alçak uçuş yaparak gelenleri selamlar. Deniz kenarındaki evlerin önünden geçen otomobiller görülür. Fonda 10. Yıl Marşı çalmaya başlar. SSCB Türkiye Büyükelçisi Hüseyin Ragıp Bey (10:39): Büyükelçi Ragıp Bey fötr şapkası, yuvarlak çerçevesiz gözlüğü ve elinde sigarasıyla görülür. Akademisyen G. M. Krujijanovskiy (10:50): Bu akademisyen de tıpkı Ragıp Bey gibi fötr şapkalı ve top sakallıdır ve yine o da sigara içer. Bu akademisyen de yakın çekim olarak gösterilir. Ardından, küçük bir teknede konuklara el sallayan insanlar görülür. Teknenin yanına asılan pankartta "neft sendika işçilerinden aziz misafirlere selam" yazılıdır. Tekneye Türk ve Sovyet bayrakları asılıdır. Çok sayıda küçük tekne karşılama için ordadır. Fonda 10. Yıl Marşı seslendirilmektedir. İzmir görüntülerinin hemen ardından çerçeve yazı kullanılmadan İstanbul görüntülerine geçilir. Deniz kenarındaki yalılar ve elindeki dürbünüyle bunları seyreden bir Sovyet subayı görülür. Perdede Rumeli Hisarı ve Ortaköy Camii belirir. Geminin içinde fötr şapka ve frak giymiş konuklar, Dolmabahçe Sarayı'nın önünden geçerler.

İstanbul! (14:03): Denizden Sultanahmet, Ayasofya ve Süleymaniye Camileri görülür. Akabinde heyeti getiren gemi ve rıhtımda heyeti karşılamaya gelen vatandaşlar görülür. Rusça pankartlar asılıdır. Bando marş çalmaktadır. Sırasıyla karşılamaya gelen küçük tekneler, Karaköy'deki liman ile Türk ve Sovyet bayraklarının asıldığı otel görülür. Heyet üyelerine çiçek takdim edilir.

Aynı gün Sovyet Heyeti Ankara'ya gitti (15:29): Önünde Türk bayrağı bulunan bir lokomotifin görüntüsü ve sesi perdeye yansır. Ardından heyeti karşılamaya gelen asker ve siviller görülür. General Muzaffer Paşa (15:50): Türk ve Sovyet subaylar sohbet ederken görülürler. Ardından tren yolu gösterilir. Ankara'ya (16:07): Anakara’nın uçaktan yapılan çekimleri gösterilir. Ankara yeni Türkiye'nin başkenti (16:23): Yine Ankara’nın uçaktan çekilen görüntüleri gösterilir. Kale ve eski semt (16:35): Ankara Kalesi ve etrafı uçaktan gösterilir. Yeni Ankara (16:55): Ankaraya yeni yapılan binalar, caddeler ve atlı Atatürk heykeli, uçaktan görülür.

Devlet başkanının köşkü (17:18): Türkiye Cumhuriyeti’nin kurucusu ve ilk cumhurbaşkanı Mustafa Kemal Atatürk’ün ikamet ettiği Çankaya Köşü̉nün uçaktan görüntüsü verilir. Ardından Ankara Garı’nda Türk ve Sovyet bayraklarının dalgalandığı görülür. Bekleyenler fötr şapkalıdır. 10. Yıl kutlamaları için hazırlanmış platform gözükür. İzciler, konukları beklemektedirler. Genç bir izci kız yakın çekimde gösterilir. Önünde Türk bayrağı asılı olan tren gara giriş yapar. İzci bir genç erkek, İnönü Oymağı yazılı bir flamayla beklemektedir. Hemen arkasından önceki izci kızın görüntüsü yeniden gösterilir. Gelenleri karşılamak için Rusça bir ibare de asılmıştır. Trenden yol boyunca dizilen askerler gösterilir. Şapkalı vatandaşlar ve izciler Sovyet Heyeti’ni coşkuyla karşılarlar. İzci genç kızlar topluca baş selamı verirler. Garda bekleyenler arasında İsmet (İnönü) Paşa görülür. İsmet Paşa ve Türk subaylar konukları karşılar. İstiklal Marşı fondayken Sovyet heyeti, Türk askerleri selamlar. Ankara Garı'nın giriş kapısının solunda Türk bayrağı, sağında Sovyet bayrağı asılıdır. Orak çekiç amblemi ve Rusça bir ibarenin olduğu anıt tekrar gösterilir. Fonda İstiklal Marşı çalınmaya devam 
etmektedir.

Devlet başkanının konuşmasından sonra tören başladı (19:33): Tören alanındaki resmi geçit gösterilir. Sovyet subayları dışındaki yabancı üst düzey subaylar da töreni izlemektedirler. Genel Kurmay Başkanı Fevzi Paşa (20:36): Fevzi (Çakmak) Paşa töreni izlemektedir. Askeri bando marş çalarken görülür. Türk subay ve askerler resmigeçit yaparken, yabancı üst düzey subaylar da onları seyreder. Geçit yapan birliklerin atları da vardır. Şeref tribünümde Mustafa Kemal (Atatürk) görülür, arkasındaki görevliye direktif vermektedir. Yakasında altı ok vardır ve papyonludur. Sonrasında yabancı askeri temsilciler tekrar görülür. Ardından atlı top arabaları ve tanklar geçer. Yaşlı bir gazi, yanındaki genç izci kıza, resmigeçit yapan uçakları göstererek "Muharebeden evvel bunlardan iki tanecik vardı. Şimdi çok var." der. Ellerinde "İnönü Oymağı” yazılı bir flama taşıyan izciler geçerler. Sonrasında Mustafa Kemal (Atatürk) tekrar gösterilir. Elinde sigara vardır, beyaz papyonludur, ceket cebinde mendil ve yakasında altı ok vardır. Ellerinde üstünde altı ok figürü bulunan sopalar tutan bir grup geçer. Fonda 10. Yıl Marşı çalmaktadır. Seymenler geçerler. Onların da bazılarının elinde altı ok var. Işıklandırılmış “hoş geldin” yazısı görülür. Arkada 10 rakamı yanıp söner. Işıkland1rılmış bina, cadde ve sokak görüntüleri gösterilir.

Sovyet Heyeti konuksever ve dost Türkiye'yi terk etti. (27:40): Trenin arkasından koşarak heyeti uğurlayan halk ve merdivenden halka el sallayan heyet üyesi görülür. Son (28:20): Bu çerçeve yazıyla ilk bölüm biter. Birinci bölümün sonuyla ikinci bölüm arasında " 3 " yazan bir çerçeve yazı görülür.

Ankara! (28:24): İki dağın üzerine kurulmuş bir şehir görüntüsü gösterilir. Ankara nedir? (28:31): "Encyclopedia Britannica Dictionary"nin ilk sayfası görülür. Bir el sayfaları karıştırır ve Ankara maddesine gelir. Anakara 500 futluk çıplak bir tepe üzerine kurulmuştur. (28:52), Çok güzel Yunan Roma ve Bizans mimarisi kalıntıları vardır. Bunların arasında Ogüst Tapınağı kalıntıları özellikle ilgi çekmektedir. (29:05): Ogüst Tapınağı'nın kalıntılardan görüntüler gösterilir. Eski Anadolu evlerinin önünde sergilenen antik heykeller görüntülenir. Eski Ankara birçok tarihi olay yaşadı ve duvarları arasında yüksek kültür abidelerini muhafaza eti (30:10): İçlerinde kaplumbağa ve aslan heykellerinin de bulunduğu antik eserler görülür. Ankara o zamandan bu yana Cumhuriyet' in başkenti oldu... (30:40): Tarihi bir binanın çatısının iç kısmı, iki şerefeli bir minare ve arkasından çorak Ankara toprakları görülür.

Dar, karanlık, düzgün olmayan sokakları vardı ve en kalabalık yolları dahi tozluydu. Yapılı değildi. (30:57): Ankara’nın kıraç topraklarına bakan bir yerde, bir anne ve dört çocuğu oturmuş yünle uğraşıyorlar. Ardından harabe bir köyde sepetle bir şey taşıyan iki kadın görülür. Sonra sırasıyla, yıkık tek katlı bir evin yanında bekleyen kediler, duvar yapan yaşlı bir vatandaş, çamaşırları seren bir kadın, tenekeyle bir şeyler götüren kasketli bir vatandaş gösterilir. Akabinde köyden başka sahnelere geçilir. Bir evin içinde bir kadın, çocuğu ve bir köpek vardır. Ata binmiş bir bebek, yanında başka bir çocuk ve arkada bir kadın. Yakın çekim yapılan çocuk mutlu değildir, ağlamaktadır... Ağzının yanında yaralar vardır. Daha sonra, at arabasında oturan dört çocuk, arabaya bağlı inek ve yavrusunun arkasında yüzünü gizleyen çarlı bir kadın ile fesli, sakallı ve sigara içen yaşlı bir adam gösterilir.

Eski Ankara’nın daracık sokakları geçmişe gidiyorlar (32:56): İlk önce küçük evlerin ve küçük minareli bir caminin olduğu genel bir Ankara görüntüsü gösterilir. Daha sonra sırasıyla kalabalık ve dar sokakları, at binen insanlar, kalabalık içinde bir otomobil, kasketli insanların arasından yürüyen kovboy şapkalı ve muhtemelen sırt çantalı, turist görünümlü bir kişi, 
telgraf direkleri, geleneksel giysileri içinde bir orta yaşl1, minderlere gelişigüzel yaslanmış bir erkek, fötr şapkalı ve bastonlu sakallı yaşlı bir adam, yanında ondan daha genç, kirli sakallı ve sigara içen fötr şapkalı başka bir adam, eli baltalı ve eski elbiseli yaşlı bir lahana satıcısı, pazar yerinde alışveriş yapan insanlar, çar giyen kadınlar, hamallar, iki yanına astığı tenekeyle su taşıyan kadın, tavuk satan yaşlı adam, güvercin satıcısı, sigara içen kumaş satıcısı, ayakkabı tamircisi, ince belli bardakla cay servisi yapan kahveci, bakımsız evler, elbise diken küçük çocuk, berber dükkânı, koyun satıcıları, arkalarında asılı duran birkaç çeşit Anadolu halı ve kilimi, bakır dükkânı görüntüleri gösterilir.

Sovyetler Birliği’nden gelen dostlarına ülkenin eski büyük sanatını gösterdiler. (35:37): Şehrin yukarıdan görüldüğü, Ankara’nın yüksek bir tepesinde bir şeyler için bekleyen Sovyet heyeti görülür, fonda davul zurna havası vardır. Zeybeklerin dansı (35:59): Elinde kılıçlarıyla sabit bir şekilde duran zeybekler üst üste gösterilir. Sovyet heyeti, birazdan gösteri sunacak zeybek ekibini izlemektedir. Zeybek ekibindeki küçük bir çocuk kendilerini seyreden heyet üyelerine birkaç figür gösterir. Zeybeklerin gösterisi devam ederken sahneye kadınlardan oluşan bir halkoyunu ekibi çıkar. Arada heyetin ve zeybeklerin görüntüleri verilmekle birlikte özellikle halkoyunları ekibindeki iki kadın yakın çekimle gösterilir. Kadınların fotojenik olmaları ve makyajları dikkat çeker. Akabinde filmin ilk bölümünde perdeye yansıyan yaşlı gazi ve genç izci kız, yeniden görünürler.

İşte 15 yıldır kendi devlet başkanı tarafından yönetilen Türk halkı... (39:09): Elinde tüfeği olan ve ufka bakan bir Türk askerinin ve cepheye top taşıyan bir Türk kadınının heykelleri gösterilir. ...Yeni Türkiye için mücadele... (39:28): Atlı Atatürk heykelleri ve yine o yaşlı gazi ve genç izci kız görülür. Düzenlenmiş Ulus Meydanı ve buradaki Atatürk heykeli gösterilir. Heykelin yakınındaki binaların birinde Goodyear lastiklerinin reklamı vardır. Düzenli cadde, telefon direği ebatlarında sokak saatleri, Millet Meclisi ve otel, modern binalar ve otomobiller arka arkaya perdeye yansir.

29 Ekim 1923'te Büyük Millet Meclisi’nin Türkiye'yi “cumhuriyet” ilan ettiği bina (40:13): Meclis binasının önünde nöbet tutan askerler ve otomobillerin görüntüsünden sonra Cumhuriyet Halk Fırkası'nın o dönem kullanılan logosu görülür. Logonun altında "cumhuriyetçiyiz, milliyetçiyiz, devletçiyiz, laikiz, inkılâpçıyız" yazısı vardır. Siyah ve yuvarlak şekilli logonun solunda aynı ebatlarda, belki başka bir kurumun logosu olan, beyaz bir daire vardır. Zincirle bağlı bir güllenin arkasında silahlı bir asker nöbet tutmaktadır. Arka planda Türk bayrağı görülür.

Şehir büyüyor, yeni hükümet binaları büyüyor (40:41): Bu kısımda Ankara’ya yeni yapılan devlet binaları gösterilir. Genelkurmay Başkanlığı ve bir okul binası olabilir. Bankalar. (41:23): Ulus'taki asker heykelinin arkasında muhtemelen Ziraat Bankası'nın binası görülür. Bilimsel kuruluşlar (41:48): Bir kimya laboratuarı görülür. Üzerinde saat olan bir bina daha perdede belirir. Yüksek Ziraat Enstitüsü (42:58): Enstitü binası görülür. Yanında bir at bulunan ders hocası, öğrencilere ders anlatmaktadır. Kız ve erkek öğrenciler dersi beraberce dinlemektedirler. Halkevi (43:41): Atlı Atatürk heykeli ve arkasından bir aslan heykeli görülür. Arkasından Etnoğrafya Müzesi’nin tabelası, müzenin girişi ve sütunları gösterilir. Sağlık Bakanlığı (44:13): Bakanlığın modern binası görülür, önünden otomobiller geçmektedir. Binanın önünde fıskiyeli bir havuz vardır. Numune Hastanesi’nin büyük binası gösterilir. Örnek hastane (44:35): Numune Hastanesi tekrar gösterilir. Etraftaki binalar ve yollar oldukça düzenlidir ve önlerinden otomobiller geçmektedir. Takım elbiseli, fötr şapkalı ve kasketli adamların bulunduğu caddede trafik polisi trafiği düzenlemektedir. Sokak lambaları 
dikkat çeker. Ardından havuz başında suyla oynayan beş çocuk ve arkalarındaki kadınlar görülür. Bebek arabasıyla bir kadın geçmektedir. Bir başka iyi giyinimli kadın, çocuğuyla bankta oturmaktadır. Bir asker kucağında bir çocuk tutmaktadır.

İsmet Paşa Kız Enstitüsü (46:27): Modern okul binasının önünde geçen kız öğrenciler ve otomobiller görülür. Kız öğrenciler ve öğretmenleri modern giysiler içinde spor yapmaktadırlar. Önceki bölümlerde görülen izci genç kız ve yaşli gazi tekrar görülür. Gazi elini siper ederek ufuklara bakmaktadır. Konservatuar (47:44): Konservatuarın girişi ve içeride ve okulun bahçesinde keman, flüt çalan erkek ve kadın sanatçılar görülür. Ardından kapısının üzerinde CCCP yazan Sovyet Büyükelçiliği görülür. Yeni Ankara'nın en eski binalarından biri SSCB Büyükelçiliği'dir (48:58): Büyükelçiliğin genel görüntüsü ve binanın içerisinden Ankara’nın görüntüsü verilir. Ardından, önünde araba olan üç katlı bir bina görülür. Tarihi binalardan biri bahçesiyle beraber görülür. Meclis veya Ankara Palas olabilir. Altı katlı bir apartman ve düzenli yol görüntüsünden sonra yaşlı gazi ve yanındaki genç izci kız yeniden görülür.

Şehir, çetin Anadolu toprağında savaşarak karış karış kaybettiği yerleri geri alıyor (49:40): Bir-iki katlı düzenli bahçeli evler görülür. Etrafta geniş boş araziler var. Modern bir altı katlı bina ve önünde estetik fıskiye görülür. Önceki bölümlerde görülen izci genç kız, "Bu bizim şimdiki halimiz, yeni halimiz, yeni hayatımız." derken yaşlı gazi, Mustafa Kemal (Atatürk)'i kastederek, "Yarın Başkumandanım Gazi'yi göreceğim." der.

29 Ekim 1933. (50:45): Tören alanında dizilmiş atlı askerler, şapkalı ve kasketli vatandaşlar görülür. Muhtemelen bu filmi hazırlayan Sovyet sinemacılar, kameraları başında gözükürler. Cumhuriyet'in Devlet Başkanı Gazi Mustafa Kemal (51:02): Atatürk’ün maiyetiyle birlikte Türkiye Büyük Millet Meclisi’nden çıkışı görülür. Konuşma Cumhuriyet'in 10. Yılına ithaf edildi. (51:16): Atatürk otomobille tören alanına gelir. Misafirler ayağa kalkar. Fonda İstiklal Marşı çalınır. Atatürk arabasından iner, melon şapka giymiştir. Konuk yabancı askerler onu asker selamıyla karşılarlar. Atatürk beyaz gömlek giymiş ve beyaz papyon takmıştır, yakasında altı ok amblemi olan bir frak giymiştir.

Cumhuriyetin devlet başkanı konuşmasına şöyle başladı: Türk halkı! 15 yıl önce bağımsızlık savaşını başlattık. (51:43): İki kamera ve arkasından Atatürk görülür. Atatürk’ün arkasında onun gibi giyinmiş başta Başbakan İsmet (İnönü) Paşa olmak üzere devlet adamları vardır. Atatürk 10. Yıl Nutku'nu okumaya başlar:

Bugün Cumhuriyetimizin onuncu yılını doldurduğu en büyük bayramdır. Kutlu olsun! Şu anda, büyük Türk milletinin bir ferdi olarak, bu kutlu güne kavuşmanın en derin sevinci ve heyecanı içindeyim.

Yurttaşlarım! Az zamanda çok ve büyük işler yaptık. Bu işlerin en büyüğü, temeli, Türk kahramanlığı ve yüksek Türk kültürü olan Türkiye Cumhuriyetidir. Bundaki muvaffakiyeti, Türk milletinin ve onun değerli ordusunun bir ve beraber olarak, azimkârane yürümesine borçluyuz. Fakat yaptıklarımızı asla kâfi göremeyiz; çünkü daha çok ve daha büyük işler yapmak mecburiyetinde ve azmindeyiz.

Yurdumuzu, dünyanın en mamur ve en medenî memleketleri seviyesine çıkaracağız. Milletimizi, en geniş, refah, vasıta ve Kaynakçaina sahip kılacağız. Millî kültürümüzü, muasır medeniyet seviyesinin üstüne çıkaracağız. Bunun için, bizce zaman ölçüsü, geçmiş asırların gevşetici zihniyetine göre değil, asrımızın sürat ve hareket mefhumuna göre düşünülmelidir. Geçen zamana nispetle daha 
çok çalışacağız, daha az zamanda daha büyük işler başaracağız. Bunda da muvaffak olacağımıza şüphem yoktur. Çünkü Türk milletinin karakteri yüksektir; Türk milleti çalışkandır; Türk milleti zekidir.”

Cumhuriyet'in devlet başkanı sonsuz inancını dile getiriyor ki Türk halkı (52:56):, Önünde duran görevleri başarıyla yerine getirmekte ve büyük millet adını haklı çıkarmaktadır (53:00):, Türk halkının üstün özelliklerine işaret eden cumhuriyetin devlet başkanı duyuruyor ki, artık büyük başarılar elde eden Türkiye (54:08):, Milli kültürünün inşasında kültür, bilim ve sanatın seviyesini daha da yükseltmek gereklidir. (54:22): Asker heykelleri, resmi geçit yapan askerler, yeni yapılan inşaatlar, Ankarảnın uçaktan görüntüleri, baraj yapım çalışması ve Mensucat Fabrikası gösterilir. Filmin sonunda fondaki 10. Yıl Marşı eşliğinde yaşlı gazi ve genç izci kız ellerini sallarlar. Atatürk ve sevinen genç kızlar görülür.

\section{Sonuç}

Kurtuluş Savaşı’nın devam ettiği günlerde Batılı güçlere karşı birbirleriyle işbirliği yapma ihtiyacı sonucu ortaya çıkan ve II. Dünya Savaşı sonuna kadar devam eden Türkiye - Sovyetler Birliği ilişkilerinin, siyasal ve ekonomik yönlerinin yanında sanatsal bir boyutu da vardır. Bu kapsamda iki ülke çeşitli sanat dallarında etkileşim içinde olmuşlardır. Bu sanatsal etkileşimin önemli bir kısmını sinema alanındaki faaliyetler oluşturur. 1920’ler ve 1930'larda Sovyetler'in sinema alanında çok başarılı olmaları, Türk hükümetinde sinema alanında Sovyetler'le işbirliği yapma isteği uyandırmıştır. Her ne kadar Muhsin Ertuğrul gibi bazı Türk sinemacılar Sovyetler'e gidip gözlemlerde bulunsa da bu işbirliğinden Türk sanatçıların çok fazla bir fayda temin ettiğini söylemek zordur. Bu işbirliğinin somut tarafı, Türkiye'nin Sovyetler'den çeşitli alanlarda eğitici filmler ithal etmesi olmuştur. Bunun yanı sıra Sovyet sinemacıların 1930'larda çektikleri ve Türkiye’nin o günkü koşullarını, Cumhuriyet kutlamalarını ve Atatürk’ün görüntülerini barındıran filmler, dönemin koşullarını yansıtmaları nedeniyle tarihsel açıdan çok önemlidirler.

Cumhuriyet'in ilanının onuncu yılı olan 1933 yılında Türkiye’ye davet edilen Sovyet yönetmenler tarafından çekimi yapılan "Ankara: Türkiye’nin Kalbi” belgeselinin en önemli özelliği, yeni kurulan Türkiye Cumhuriyeti’nin on yılda aldığı mesafeyi yansıtmayı amaçlamış olmasıdır. Bu amaçla, filmde 1923’ten önceki eski dönem ile 1923-1933 yılları arasındaki on yıllık yeni dönemi sembolize etmek için birçok görüntü ve metin kullanılmıştır. Bunlardan en fazla ön plana çıarılanı yaşlı gazi ile genç izci kız tiplemeleridir. Burada "yaşlı gazi” eski, yorulmuş, yıpranmış geçmişi yani eskiyi sembolize ederken; yanındaki genç izci kız, yeni, genç, dinamik ve modern yeni devlet ve toplumu sembolize etmektedir. Karşılamalarda ve resmigeçitlerde askeri alandaki gelişmenin bir göstergesi olarak sunulan uçak, gemi ve tankların geçişlerinde yaşlı bir gazi, yanındaki genç izci kıza, uçakları göstererek "Muharebeden evvel bunlardan iki tanecik vardı. Şimdi çok var." derken önceki dönemle şimdiki dönem arasındaki gelişmişlik farkını vurgulamaktadır. Başka bir sahnede ise bu farkı vurgulamak genç izci kıza düşer. Modern bina görüntülerinden sonra izci kız, "Bu bizim şimdiki halimiz, yeni halimiz, yeni hayatımız." der.

Filmin hemen başındaki çoban, sürü, eşek, deve ve çorak arazi görüntüleri, Türkiye’nin geçmişte toprağa bağımlı bir ziraat ülkesi olduğu ve bu ülke insanlarının fakir olduğunu göstermektedir. Ankara'ya doğru yola çıkan kişinin yaşlı olması, savaşlarda gençlerini kaybeden Türkiye’nin nüfusunun yaşlılığını; eşekle gitmesi, ülkedeki ulaşım araçlarının yetersizliğin; duvar yapan yaşlı adam ve hasta görünüşlü çocuk, kırsaldaki üretim ve sağlık koşullarının 
kötülügünün; yüzünü gizleyen kadın, kadınların sosyal hayattan uzaklaştırılmış olduklarının; kadınların yün eğirmesi ve kağnıların yürütülmesi ise fakirliğin göstergesi olarak sunulmuştur. Bunun hemen sonrasında ise trenlerin ve coşkulu gençlerin gösterilmesi ise on senede alınan mesafe olarak sunulmaktadır. Yani genç ve modern bir nesil yetiştirilmiş, eşeğin yerini tren almıştır. Gençlerin kız ve erkeklerden oluşması, artık kadın erkek ayrımının yapılmadığının göstergesidir.

Eski Ankara sokaklarında, yaşlı bir lahana satıcısı, pazar yerinde alışveriş yapan insanlar, çar giyen kadınlar, hamallar, iki yanına astığı tenekeyle su taşıyan kadın, tavuk satan yaşlı adam, güvercin satıcısı, sigara içen kumaş satıcısı, ayakkabı tamircisi, ince belli bardakla cay servisi yapan kahveci, bakımsız evler, elbise diken küçük çocuk, berber dükkânı, koyun satıcıları, arkalarında asılı duran birkaç çeşit Anadolu halı ve kilimi, bakır dükkânı görüntüleri Ankara’nın ekonomisinin küçük ölçekli geleneksel ticarete dayandığının göstergesidir. Bunların sonrasında gösterilen fabrika, baraj ve modern bina görüntüleri ticaret ve sanayi alanındaki değişimi göstermektedir. Ulus'taki Atatürk heykelinin yakınındaki binaların birinde Goodyear lastiklerinin reklamı olması, ülke ekonomisinin dünya ekonomisi ile entegrasyonunun göstergesidir. Düzenli caddeler, telefon direği ebatlarında sokak saatleri, sokak lambaları, oteller, modern binalar ve otomobiller, trafiği düzenleyen trafik polisi, havuz başında suyla oynayan çocuklar ve arkalarındaki modern görünümlü kadınlar, ülkenin daha düzenli, modern ve müreffeh bir hale geldiğinin göstergeleridir.

Halkın ve devlet yetkililerinin Sovyet heyetine gösterdiği ilgi 1933 yılında Türkiye- Sovyetler Birliği ilişkilerinin yoğunluğun bir göstergesidir. İzmir’e Sovyet heyetinin karşılamaya gelen teknelerden birinin üzerindeki pankartta yazan "neft sendika işçilerinden aziz misafirlere selam” yazısı Türkiye'deki sendikaların 1930'larda da sosyalist düşüncelere gösterdiği sempatinin göstergesidir. Savaş uçakları, gemiler ve tankların gösterilmesi askeri alandaki ilerlemenin göstergesi olarak alınabilirken, yabancı subayların törende hazır bulunması ise uluslararası alanda itibar kazanıldığının bir göstergesidir. Antik eserlerin gösterilmesi, Cumhuriyet'in geçmişe sahip çıktığının tarihi eserlere değer verdiğinin belirtisidir.

Filmin hemen başında, Bakanlar Kurulu Başkanı İsmet Paşa Filmimizin Cumhuriyetin 10. Yılına İthaf Edilen Bir Konuşma Yaptı şeklinde bir çerçeve yazı olmasına rağmen buna dair bir görüntü yoktur. İsmet (İnönü) Paşa filmde çok az görülür. Ellerinde "İnönü Oymağı" yazılı bir flama taşıyarak resmigeçide katılan izciler, "Inönü” isminin yeni devlet açısından sembolik anlamını belirtirler. Mustafa Kemal (Atatürk), Milli Mücadele’nin karizmatik komutanı ve Cumhuriyet'in kurucu cumhurbaşkanı olarak filmde yerini alır. "Ankara: Türkiye'nin Kalbi" filmi, estetik açıdan herhangi bir iddia taşımasa da dönemin Türkiyesi’nin siyasal, ekonomik ve askeri alandaki görüntüsünü yansıtması açısından tarihsel bir değer taşımaktadır. 


\section{Kaynakça}

Ahmad, Feroz, Modern Türkiye’nin Oluşumu, Çev. Yavuz Alogan, İstanbul: Kaynak Yayınları, 6. baskı, 2007.

Akçura, Gökhan, Doğumunun Yüzüncü Yllına Armağan: Muhsin Ertuğrul, İstanbul: Kültür İşleri Daire Başkanlığı Yayınları, 1992.

Altınkurt, Lale, “Türkiyede Sanat Eğitiminin Gelişimi”. http://sbe.dpu.edu.tr/12/125-136. pdf (15-02-2011).

Arlı, Alim, "Cumhuriyet Döneminde Türkiyede Şehirleşme ve Gecekondu Araştırmaları", Türkiye Araştırmaları Literatür Dergisi, III(6), 2005.

Atatürkün Söylev ve Demeçleri II., 5. Baskı, Ankara: ADTYK Atatürk Araştırma Merkezi Yayınları, 1997.

Balcıoğlu, Mustafa, "Cumhuriyet Dönemi Dış Politikası”, Türkiye Cumhuriyeti Tarihi, Cilt:II, Ankara: AKDTYK Atatürk Araştırma Merkezi, 2005.

Balcıoğlu, Mustafa, "Direnen Millet - Milli Mücedele: Ya İstiklâl Ya Ölüm”, Türkiye Cumhuriyeti Tarihi, Cilt:I, Ankara: AKDTYK Atatürk Araştırma Merkezi, 2005.

Batuman, Bülent, "Mekân, Kimlik ve Sosyal Çatışma: Cumhuriyet'in Kamusal Mekânı Olarak Kızılay Meydanı”, Ankara’nın Kamusal Yüzleri, Der. Güven Arif Sargın, İstanbul: İletişim Yayınları, 2002.

Berger, John, Sanat ve Devrim, Çev. Bige Berker, İstanbul: Agora Kitaplı̆̆ı, 2007.

Berkes, Niyazi, Unutulan Yıllar, İstanbul: İletişim Yayınları, 1997.

Berktaş, Esin, “1939-1950 Dönemi Türk Sinemasının Ekonomik, Politik, Toplumsal ve Kültürel Yapısı”, Sanatta Yeterlilik Tezi, İstanbul: Mimar Sinan Güzel Sanatlar Üniversitesi Sosyal Bilimler Enstitüsü Sinema-Tv Ana Sanat Dalı Sinema-Tv Programı, 2008.

Boztepe, Veli, "1960 ve 1980 Askeri Darbelerinin Türk Siyasal Sinemasına Etkileri”, Yüksek Lisans Tezi, İstanbul: Marmara Üniversitesi Sosyal Bilimler Enstitüsü İletişim Bilimleri Anabilim Dalı Radyo Televizyon Bilim Dalı, 2007.

Budak, Kürşat, "20. Y.y. Resim Sanatında Ulusal Eğilimler”, Yüksek Lisans Tezi, Erzurum: Atatürk Üniversitesi Sosyal Bilimler Enstitüsü, Resim Anasanat Dalı, 2008.

Çiçek, Erdoğan, "Günümüzde Devletler Tarafından Uygulanan Psikolojik Operasyonlar Teorisi”, Yüksek Lisans Tezi, Ankara: Kara Harp Okulu Savunma Bilimler Enstitüsü Güvenlik Bilimleri Ana Bilim Dalı, 2006.

“D grupu ressamları", Cumhuriyet, 31 Mart 1934, s. 2.

Egeli, Münir Hayri, “Gezgin Tiyatrolar”, VI(34), 1935.

Elmas, Hüseyin, “Ondokuzuncu Yüzyıldan Günümüze Özgürlük Bağlamında Sanat Neydi, Ne Oldu?". http://www.sosyalbil.selcuk.edu.tr/sos_mak/makaleler/H\%C3\%BCseyin\%20 ELMAS/ELMAS,\%20H\%C3\%BCseyin.pdf (01-02-2011).

Erbay, Fethiye; Erbay, Mutlu, Cumhuriyet Dönemi (1923-1938) Atatürk’ün Sanat Politikası, İstanbul: Boğaziçi Üniversitesi, 2006.

Ertekin, Sibel, “Türk Operasının Gelişim Süreci”, Yüksek Lisans Tezi, Ankara: Başkent Üniversitesi Sosyal Bilimler Enstitüsü Müzik ve Sahne Sanatları Anabilim Dalı Müzik Bilimi, 2007.

Gezer, Hüseyin, Cumhuriyet Dönemi Türk Heykeli, 3. baskı, Ankara: Türkiye İş Bankası Kültür Yayınları, 1984. 
Gsell, Paul, “Sovyet Memleketinde Tiyatro”, Yeni Adam, 25 Haziran 1934.

İnan, Arı (der.), Düşünceleriyle Atatürk, 3. baskı, Sadeleştiren: İsmet Parmaksızoğlu, Ankara: AKDTYK Türk Tarih Kurumu Yayınları, 1999.

Karadağ, Esen, "Cumhuriyet Dönemi Kadın Sanatçıların Resim Öğretimindeki Rolü", Yüksek Lisans Tezi, Samsun: Ondokuzmayıs Üniversitesi Sosyal Bilimler Enstitüsü Güzel Sanatlar Eğitimi Anabilim Dalı, 2008.

Kılınç, Kıvanç, “Öncü Halk Sağlığı Projelerinin Kamusal Mekânı Olarak Sıhhiye”, Ankara’nın Kamusal Yüzleri, Der. Güven Arif Sargın, İstanbul: İletişim Yayınları, 2002.

Mahmudoğlu, Mahad Sofiev, "Sovyet Kültürünün Türkiye Üstündeki Olumlu Etkileri”, Toplumsal Tarih, VIII(48), 1997.

McNeill, William H., Dünya Tarihi, Çev. Alâeddin Şenel, 5. baskı, Ankara: İmge Kitabevi, 2001.

“Moskovada Türk resim sergisi”, Cumhuriyet, 2 İkincikanun (Ocak) 1936, s. 1.

“Moskovadaki Türk resim sergisi”, Cumhuriyet, 20 İkincikanun (Ocak) 1936, s. 9.

Oylum, Rıza, Rus Sineması, İstanbul: Başka Yerler, 2011.

Ödekan, Ayla, "Mimarlık ve Sanat Tarihi”, Türkiye Tarihi, Cilt:IV, Çağdaş Türkiye 1908-1980, Yay. Yön.: Sina Akşin, 9. baskı, İstanbul: Cem Yayınevi, 2007.

Öndin, Nilüfer, Cumhuriyet'in Kültür Politikası ve Sanat 1923-1950, İstanbul: İnsancıl Yayınları, 2003.

Özgür, Murat, “Güneydoğu Anaolu Bölgesi’ndeki Atatürk Anıtları”, Yüksek Lisans Tezi, Van: Yüzüncü Yıl Üniversitesi Sosyal Bilimler Enstitüsü Sanat Tarihi Anabilim Dalı Genel Sanat Tarihi Bilim Dalı, 2005.

Özön, Nijat, Karagözden Sinemaya Türk Sineması ve Sorunları, Cilt:II, Ankara: Kitle Yayınlar1, 1995.

Öztürk, Serdar, Erken Cumhuriyet Döneminde Sinema Seyir Siyaset, Ankara: Elips Kitap, 2005.

"Sovyet Artistleri Memleketlerine Döndüler", Tan, 17 Mayıs 1935, s. 11.

"Sovyet Artistlerinin Konseri", Tan, 1 Mayıs 1935, s. 3.

"Sütçülük için bir film”, Tan, 18 Haziran 1935, s. 2.

Şahin, Mustafa; Duman, Ruşen, "Cumhuriyet'in Yapılanma Sürecinde Müzik Eğitimi”, Çağdaş Türkiye Tarihi Araştırmaları Dergisi, VII(16-17), 2008.

Şenol Cantek, L. Funda, "Yaban”lar ve Yerliler Başkent Olma Sürecinde Ankara, İstanbul: İletişim Yayınları, 2003.

Şentürk, Nezihe, "Atatürk’ün Özdeyişlerinde Kültür Sanat Müzik Yaklaşımı", Uluslararası Atatürk ve Güzel Sanatlar Sempozyumu Bildirileri, Haz. Nail Tan, Hayrettin İvgin, Ankara: 26-27 Ekim 2001.

Şimşir, Bilal, Ankara... Ankara Bir Başkentin Doğuşu, Ankara: Bilgi Yayınevi, 1988.

Tacibayev, Raşid, Kızıl Meydan'dan Taksime, İstanbul: Truva Yayınları, 2004.

Tansuğ, Sezer, Çağdaş Türk Sanatı, 4.baskı., İstanbul: Remzi Kitabevi, 1996.

Taş, Murat, "Osmanlıdan Günümüze Yapı Üretiminde Mimarlık Meslek Örgütlenmesinin Gelişimi”, Uludă̆ Üniversitesi Mühendislik-Mimarlık Fakültesi Dergisi, VIII(1), 2003.

Tekeli, İlhan, "Cumhuriyetin Çağdaşlaşma Projesinin Mekansal Boyutu Üzerine Bir Değerlendirme”, Ankara, V. Türk Kültürü Kongresi: Cumhuriyetten Günümüze Türk 
Kültürünün Dünü, Bugünü ve Geleceği, 17-21 Aralık 2002; Mimari ve Çevre Kültürü, Cilt:VIII, Haz. Azize Aktaş Yasa, Ankara: Atatürk Kültür Merkezi Yayınları, 2005.

Turan, Ömer, “1930’lardaki 'Şehircilik Tartışmaları' Cumhuriyetin Kamusal Alanını Oluşturması”, Toplumsal Tarih, XV(85), 2001.

Türkeş, Ömer, “Güdük Bir Edebiyat Kanonu”, Modern Türkiye’de Siyasî Düşünce, Cilt:II, Kemalizm, 6. baskı, İstanbul: İletişim Yayınları, 2009.

“Türkiye’nin kalbi Ankara' filmi”, Cumhuriyet, 18 Mart 1934, s. 5.

Uluskan, Seda Bayındır, Atatürk'ün Sosyal ve Kültürel Politikaları, Ankara: AKDTYK Atatürk Araştırma Merkezi, 2010.

Uygur, Erdoğan, "Sosyalist Realizm Kavramının Ortaya Çıkış Süreci”, Türkiye Sosyal Araştırmalar Dergisi-Turkish Journal of Social Research, 9(1-2, 23-30) 2005.

Vandov, Dimitır, Atatürk Dönemi Türk-Sovyet İlişkileri, İstanbul: Kaynak Yayınları, 2014.

Yavuz, Fehmi, “Başkent Ankara ve Jansen”, O.D.T.Ü. Mimarlık Fakültesi Dergisi, VII(1), 1981.

Yılmaz, Mustafa, "Yeni Türk Devletinin Dıș İlişkileri (1923-1938)", Atatürk ve Türk İnkılâp Tarihi, Ed: Fatma Acun, 11. bask1, Ankara: Siyasal Kitabevi.

Zürcher, Erik Jan, Modernleşen Türkiye’nin Tarihi, Çev. Yasemin Saner Gönen, İstanbul: İletişim Yayınları, 20. baskı, 2006.

Arşiv Belgeleri: BCA, 030.10-146-44-11, s.2.; BCA, 030.10-146-44-11, s.1.; BCA, 030.1801-02-52-11-16. 


\title{
Artistic Relations between the Republic of Turkey and the Soviet Union in the Early Republican Era: The Case of the Documentary "Ankara: The Heart of Turkey"
}

YALÇIN LÜLECI

\begin{abstract}
During the Independence War, the close political relations established between the governments of Ankara and Soviet Russia against western countries, continued from the declaration of the Republic in 1923 to the end of the World War II in 1945. In that era, the art constituted another dimension of the relations established by these countries that mainly focused on political, military and economic aspects. Both the Soviet Russia, which acquired an important heritage from Czarism and attributed a special role to the art in order to make propaganda for the socialist ideology, and the Republic of Turkey, which considered developing an education system in terms of western arts, supporting artists and creation of the qualified artistic works as a measure of "civilization", and which intended to benefit from the propaganda power of the art in conveying the Kemalist revolutions and doctrines to society, collaborated in the field of the art especially in 1930s. In this regard, the movie called "Ankara: The heart of Turkey", which created by the Soviet film makers who were invited by the Turkish Government in terms of the "Celebration of the Tenth Anniversary of the Foundation of the Republic" had a special place. Hence, this study covers and attempts to highlight the dimensions of the collaboration and interaction between the Republic of Turkey and the Soviet Union in the field of art in the early years of the Republic.
\end{abstract}

Keywords: Turkish-Soviet relations, Ankara: Heart of Turkey, Turkish Republic, Art, Cinema 